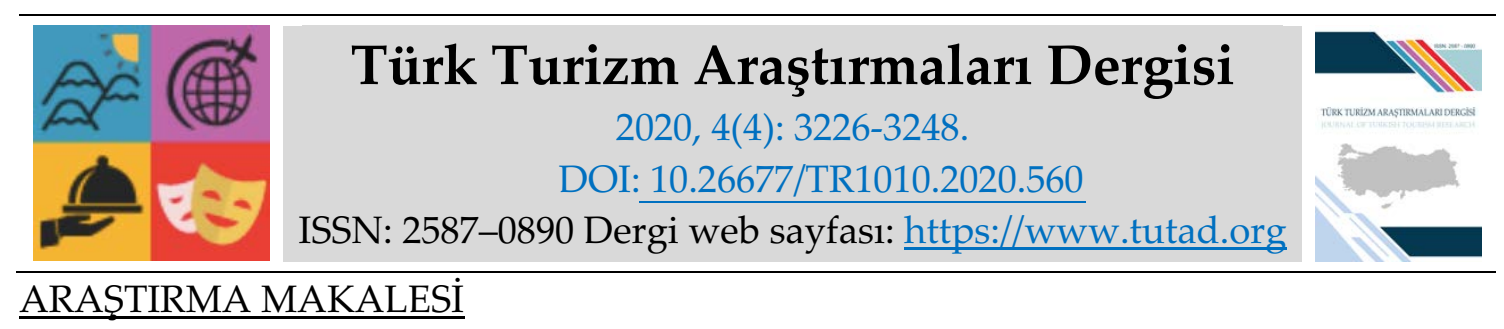

\title{
Destinasyon Pazarlamasında Gastronomik Marka İmajına Yönelik Bir Araştırma*
}

Doç. Dr. Aydın YILMAZER, Sakarya Uygulamalı Bilimler Üniversitesi, Turizm Fakültesi, Sakarya, e-posta: yilmazer@subu.edu.tr ORCID: https://orcid.org/0000-0001-8295-4745

Dr. Öğr. Üyesi Ebru Ö. GÜVEN, Sakarya Uygulamalı Bilimler Üniversitesi, Turizm Fakültesi, Sakarya, e-posta: ebruozlemguven@subu.edu.tr ORCID: https://orcid.org/0000-0003-1298-8012

Kezban GÜLŞEN, Yüksek Lisans Öğrencisi, Sakarya Uygulamalı Bilimler Üniversitesi, Turizm Fakültesi, Sakarya, e-posta: kezbangulsen03@hotmail.com

ORCID: https://orcid.org/0000-0002-6176-8174

Öz

Çalışmanın amacı, yerli turistlerin Bursa ilinin gastronomik marka imajına yönelik algılamalarının tespit edilmesidir. Bu amaca ilaveten toplanacak veriler aracılığıyla, yerli turistlerin Bursa'yı yeniden tercih etme ve başkalarına tavsiye etme gibi davranışsal niyetlerinin de ortaya çıkarılması düşünülmüş̧ür. Hedeflenen amaç doğrultusunda Bursa ilini Şubat ve Mart ayları arasında ziyaret eden yerli turistlere 601 (geçerli) anket uygulanmıştır. Ölçek olarak Likert tipi 5'li ölçeklendirme kullanılmıştır. Elde edilen sonuçlar özet tablolar ve grafikler biçiminde sunulmuştur. Analizlerde tanımlayıcı istatistikler, t-testi, Anova, güvenilirlik testi, faktör analizi yöntemleri kullanılmıştır. Tüm analizlerde anlamlılık düzeyi \%5 $(\mathrm{p}=0,05)$ olarak alınmıştır. Yapılan analizlere göre tercih edilen destinasyonlarda katılımcıların demografik yapı farklılıklarının yörenin mutfak kültürü ve yiyecek içecek çeşitliliği arasında bir ilişki olmadığı gözlemlenmiştir. Genel olarak katılımcıların Bursa iline ait yöresel yemekler hakkındaki beklentilerinin karşılandığı, yöresel yemekleri çevrelerine olumlu olarak aktardıklarını söylemek mümkündür. Ayrıca, araştırmaya katılan yerli turistlerin Bursa ilinin gastronomik marka imajının bir marka değerine sahip olduğu konusunda olumlu düşüncelere sahip olduğu gözlemlenmiştir.

* Yüksek lisans tezinden geliştirilmiştir.

Anahtar Kelimeler: Gastronomik İmaj, Bursa Mutfağı, Yerli Turist, Marka, Algı, Destinasyon.

Makale Gönderme Tarihi: 12.07.2020

Makale Kabul Tarihi: 08.10.2020

Önerilen Atıf:

Yılmazer, A., Güven, E. Ö. ve Gülşen, K. (2020). Destinasyon Pazarlamasında Gastronomik Marka İmajına Yönelik Bir Araştırma, Türk Turizm Araştırmaları Dergisi, 4(4): 3226-3248.

(C) 2020 Türk Turizm Araştırmaları Dergisi. 


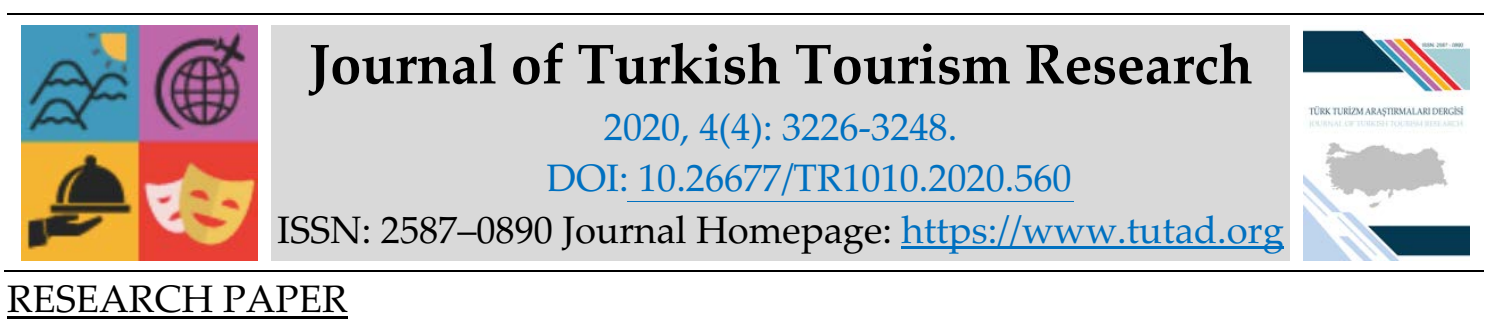

\title{
A Research on Gastronomic Brand Image in Destination Marketing
}

Associate Prof. Dr. Aydın YILMAZER, Sakarya University of Applied Sciences, Faculty of Tourism, Sakarya, e-mail: yilmazer@subu.edu.tr ORCID: https://orcid.org/0000-0001-8295-4745

Assistant Prof. Dr. Ebru Ö. GÜVEN, Sakarya University of Applied Sciences, Faculty of Tourism, Sakarya, e-mail: ebruozlemguven@subu.edu.tr ORCID: https://orcid.org/0000-0003-1298-8012

Kezban GÜLŞEN, MSc. Student, Sakarya University of Applied Sciences Faculty of Tourism, Sakarya, e-mail: kezbangulsen03@hotmail.com ORCID: https://orcid.org/0000-0002-6176-8174

\begin{abstract}
The aim of the study is to determine the perceptions of local tourists towards the gastronomic brand image of Bursa. In addition to this purpose, it was thought to reveal the behavioral intentions of local tourists such as preferring Bursa again and recommending it to others through the data to be collected. In line with the targeted purpose, 601 (valid) surveys were applied to local tourists who visited Bursa between February and March. Likert type 5-scale scaling was used as the scale. The results obtained are presented in the form of summary tables and graphics. Descriptive statistics, t-test, Anova, reliability test, factor analysis methods were used in the analyzes. The significance level was taken as $5 \%(p=0.05)$ in all analyzes. According to the analysis, it has been observed that the demographic differences of the participants in the preferred destinations are not related to the cuisine culture of the region and the variety of food and drink. In general, it is possible to say that the expectations of the participants about the local dishes of the province of Bursa were met and they convey the local foods to their surroundings in a positive way. In addition, it has been observed that the local tourists participating in the research have positive opinions about the gastronomic brand image of Bursa province as having a brand value.
\end{abstract}

Keywords: Gastronomic Image, Bursa Cuisine, Local Tourist, Brand, Perception, Destination.

Received: 12.07 .2020

Accepted: 08.10.2020

\section{Suggested Citation:}

Yılmazer, A., Güven, E. Ö. and Gülşen, K. (2020). A Research on Gastronomic Brand Image in Destination Marketing, Journal of Turkish Tourism Research, 4(4): 3226-3248.

(C) 2020 Türk Turizm Araştırmaları Dergisi. 


\section{Gíriş}

Ülkeler turizm ile ilgili potansiyellerini tanıtmada içerisinde barındırdığı doğal kaynakların yanı sıra sahip oldukları kültürlerini de ön plana çıkartmaktadır. İnsanların artan merakları ile birlikte gelişmeye başlayan gastronomi bilimi, ülkelerinde bu alana yönelik yatırım yapmaya başlamalarına neden olmuştur. Bu doğrultuda gastronomi turizmi destinasyonu ziyaret eden turistlerin o destinasyonun mutfak kültürünü daha iyi tanımak ve yöre yemeklerinin yapılışı hakkında fikir sahibi olmak, tadına bakmak gibi kavramlardan yola çıkarak gelişen alternatif bir turizm çeşidi haline gelmektedir. Ülkemiz de gerek tarihi gerekse kendine has gelişen mutfak kültürü ile gastronomi turizmi için önemli bir cazibe merkezidir. Yapılan pek çok araştırma da ülkemizin dünyaca ünü olan bir mutfak kültürüne sahip olduğunu düşünen turist sayısı oldukça fazladır. Zamanla gelişen turizm pazarında ülkemizde gastronomi turizmine yönelik pazarlama çalışmalarına devam etmektedir. Destinasyonların pazarlanması ile birlikte ülkeler, bölgeler ve kentler ekonomik refah seviyesini arttıracak ve kalkınmaya destek olacaklardır. Ülkelerin, bölgelerin ve kentlerin pazarlanmasındaki temel amaç turistlerde akılda kalıcı bir imaj yaratarak destinasyonun markalaşmasını sağlamaktır. Kentin marka haline gelmesi ile birlikte, çekicilik unsurlarına olan ilginin arttığı da gözlemlenmektedir. Destinasyonların pazarlanmasında marka imajı günümüz rekabet ortamında oldukça önemlidir.

Zengin mutfak kültürüne sahip Bursa şehri kuruluşundan itibaren gerek coğrafi yapısı gerekse barındırdığı kültürel çeşitlilikleri bakımından oldukça önem arz eden bir destinasyondur. Osmanlı Devleti'ne başkentlik yapmasının yanı sıra yaşadığı büyük göçlerle birlikte içinde çok farklı kültürleri bir arada barındırmaktadır. Bir araya gelen bu kültürel farklılıklar beraberinde şehirde yeme içme kültürün gelişmesi ve şekillenmesinde büyük rol oynamıştır. Güçlü bir geçmişe ev sahipliği yapan Bursa şehri, gerek doğal güzellikleri gerekse yöresel yemekleri ile de ülkemiz için önemli gastronomi destinasyonlarından bir tanesidir. Dolaysıyla, şehrin gastronomik açıdan tanıtımının yapılması şehri marka haline getirmek için önemli bir unsurdur. Bu bağlamda araştırmanın amacı, yerli turistlerin Bursa ilinin gastronomik marka imajına yönelik algılamalarının ve davranışsal niyetlerinin ortaya çıkarılmasıdır.

\section{KAVRAMSAL ÇERÇEVE}

\section{Marka Kavramı ve Marka İmajı}

Marka kavramı, bir işletmenin üretmiş olduğu bütün hizmetleri ve malları, diğer işletmelerden ayırt edilmesi sağlayan ve ürünün üretici ile ilgili bir imaj yaratan amblemler, simgelerdir (Uztuğ, 2002). Türk Dil Kurumu'nun terimine göre ise; ticari bir malı veya nesneyi tanıtan, diğerlerinden ayırt etmeye yardımcı olan isim veya işaretlerin tümüdür (Türk Dil Kurumu, 2019). Diğer bir tanımlamaya göre; marka kavramı terim, sembol, isim renk, işaret gibi bir takım somut görseller ile kişisel imaj ve unsurlardan meydana gelerek tüketicilerin satın alma kararlarını etkileyerek tercih etme sebebi sağlayan özelliklerin bütünüdür (Avcılar ve Varinli, 2013: 28). Markalar, ilk zamanlarda tüketim malları için ortaya çıkmış bir kavram olsa dahi günümüzde herhangi bir sektör için bağlılık yaratıcı, değer katıcı, büyümenin temel faktörü olan ve firmayı yeniliğe zorlayan adeta ruha sahip bir varlık gibidirler. Marka ve markalaşma kavramı günümüzün ekonomik sisteminde rekabet kavramının kaçınılmaz bir sonucu olarak işletmelerin bütün organizasyonel yapısını ilgilendirir (İnaç ve Yacan, 2018: 319). Tüketicilerin markayı algılamaları ve güvenmeleri, hizmeti üretenlerin imajının gelişmesinde önemlidir (Durmaz ve Ertürk, 2016: 83). Bu bağlamda marka kavramı bir işletmenin en önemli varlıklarındandır. Doğru yapıldığında en yüksek fiyatlar ile satabilmek oldukça yüksek kazançlar sağlamaktadır (Kurtbaş, 2016: 91). Marka kavramı bir işaret olmanın yanı sıra beraberinde pek çok özelliği de taşımaktadır. Marka 
olmasının altındaki sorumluluk, bu ismin korunması, kalitesinin sürekli arttırılması, beklenilen performansın altında hizmet veya ürün sunmamak böylece kalitenin sürekli bir hale gelmesini sağlar (Bişkin, 2014: 415).

Günümüzde, birbirine benzeyen ürünler arasında bir ürünü ya da hizmeti diğerinden farklı kılan özellikleri tespit etmek, oldukça zor bir süreçtir. Bu itibarla marka, tüketiciyi satın almaya teşvik eden ve yönlendiren en önemli öğelerden biri haline gelmiştir. Tüketiciler için marka algısı boyutunda, markanın işlevsel fonksiyonlarının yanında marka imajı da çok önemlidir. Marka imajı, ürüne ait çağrışımların anlamlı bir şekilde organize olması ile ortaya çıkan değerler bütünüdür (Çağlıyan vd., 2018). İmaj kavramı, bireyin zihninde bazı öğelerin etkileşimi sonucunda yavaş yavaş oluşan bir imgedir (Akkoyunlu ve Kalyoncuoğlu, 2014: 133). Tüketici alg1sı değiştikçe değişim gösterebilen marka imajı, başarılı marka yönetimi faaliyetlerinde anahtar rol oynar. Marka ile tüketici arasında sağlıklı bir ilişkide güven önemli bir unsurdur. Tüketici satın almak istediği ürüne, o ürünü üreten firmaya ve en önemlisi markaya güvenmek ister. Marka güveni, tüketicinin ilişki halinde olduğu markanın sorumluluklarını yerine getirmesiyle tüketicide oluşan pozitif tutum ve duygulardan oluşan bir değerdir (Çağlıyan vd., 2018).

Bir şehrin imajı, o şehir ile ilgili fikir ve izlenimlerden ibarettir. İmaj bir destinasyon ile ilgili onlarca bilginin sadeleşmiş halidir. Zihnimizin o yere ait birçok bilgi arasından temel olanı ortaya çıartma sürecinin bir ürünüdür. Marka imajı, destinasyon imajı gibi farklı imaj algıları bulunmaktadır. Marka imajı, somut ya da duygusal olsun tüketicinin kendi algılarıyla oluşan bir olgudur. Markanın gerçekte olanı değil tüketicinin zihninde algıladığı gerçek marka imajını oluşturur (Özüpek ve Diker, 2013: 103). Marka imajı, tüketicinin zihninde kabul edilen ve konumlanan markanın çağrışımlarıdır. Marka imajında gerçeği algılamak gerçeğin kendisinden daha önemlidir (Döner, 2019: 5). Markanın oluşturmuş olduğu gerçek değil tüketicinin algıladığ gerçek marka imajını oluşturur. Marka imajı kavramı ürün veya hizmeti üreten üreticiler ile tüketiciler arasında bir köprü vazifesi görür. Bu yüzden tüketiciler üretici veya şirketleri kendisine sunulan ürün şeklinde algılamaktadır (Turan, 2017: 654).

\section{Destinasyon Pazarlaması ve Destinasyon İmajı}

Destinasyon kavramı, turistin sürekli ikamet ettiği yerden ayrılıp, tatil, iş gezisi gibi belirli amaçlarla gideceği yerler olarak tanımlanmıştır (Bahar ve Kozak, 2005: 141). Turizm açısından destinasyon kavramına ayrıntılı bir şekilde tanımlarsak; ülke bütününden küçük ve ülke içindeki pek çok kentten büyük, insan beyninde belirli bir imaja sahip markalaşmış ulusal bir alan ve önemli turistik çekiciliklere, çekim merkezlerine, festivaller, karnavallar, farklı eğlenceler gibi çeşitli etkinliklere, bölge içinde kurulmuş iyi bir ulaşım ağına, gelişim potansiyeline, dâhili ulaşım ağıyla bağlantılı bölgeler arası ve ülke düzeyinde ulaşım olanaklarına ve turistik tesislerin gelişimi için yeterli coğrafi alana sahip bir bölge olarak tanımlanmaktadır (Tosun ve Jenkins, 1996: 522; Atılgan ve Karapınar, 2015: 116). Destinasyon pazarlaması ise, bir destinasyonun en yüksek şekilde kazanç elde etme hedefine uygun olarak ürettiği turistik ürün ve hizmetlerin hedef pazarlarda bulunmasını sağlamak amacıyla turizm talebinin özelliklerini de göz önünde bulundurarak turistik ürün ve hizmet ile ilgili araştırma, tahmin ve seçim yapma gayesinde olan ve bu konularda ilgili karar ve uygulamaları kapsayan yönetim felsefesi olarak tanımlanmaktadır (Özer, 2012: 164; Vatan ve Zengin, 2019).

Destinasyon imajı, tüketicilerin bir destinasyona yönelik sahip olduğu bilgi ve duygusal düşünceleri olarak tanımlanabilir (Vatan ve Zengin, 2019: 275). Diğer bir tanım ise, ülkelerin turistler açısından cazibe merkezi hale gelmesini ve bununla birlikte daha fazla harcama yapmalarını sağlayan, gittikleri yer hakkında zihinlerinde oluşan resme destinasyon imajı denir 
(Tunç, 2003: 39). Turistlerin yörede yaşayan halk, esnaf, diğer turistler ve çalışanlar hakkındaki izlenimlerin tamamıdır (Yaraşlı, 2007: 7). Destinasyon imajı, destinasyon pazarlamasında turizm bölgesinin kalkınmasında ve pazarlama stratejilerinin gelişmesinde vazgeçilmez bir unsurdur (Köroğlu ve Güzel, 2007: 701). Destinasyon ürünlerini veya hizmetlerini, turistlere sunarken tekrar geri gelmeleri sağlayabilme hususunda, destinasyon imajının önemi çok yüksektir (Sever ve Girgin, 2019: 243). Destinasyon, imaj ile bütünleştiğinde değer kazanmaktadır. Çünkü turistlerin seyahat edecekleri destinasyon seçiminde en önemli unsur imajdır. Turistler seyahat etmek istedikleri destinasyonları önceden araştırırlar ve bu sayede bir bilgi birimi oluştururlar. Bu birikimleri zihinlerinde oluşan imaj ile desteklerler (Ersoy, 2019: 6; İlban vd., 2008: 108). Turizm ürünü soyut ve birbirine benzer olduğu için destinasyonlar arasındaki rekabet, imaj aracılığıyla gerçekleşmektedir (Akyurt ve Atay, 2009: 4). Destinasyon imajı oluşturmak, hedefleri ve hedef pazarının isteklerini iyi anlamak ve taleplerini karşılayacak doğrultuda çalışmalar yapmaktır. Özellikle turizm açısından bir süreç oluşturmak her destinasyon bölgesinin içsel ve dışsal çevre faktörlerini ve hedef pazar isteklerinin farklı olmasından dolayı biraz zor olmaktadır (Güçlü, 2017: 33).

Turizm pazarlaması açısından destinasyon imajının geliştirilmesinde önemli olan iki ana bileşen vardır. Bunlar: Algısallık ve bilişsellik kavramı, destinasyonların, tüketicinin verdiği değer bakımından birbirlerinden üstündür. Başka bir deyimle, turistler destinasyon ziyareti davranışlarını, o bölgenin motive edici kaynaklarına ve özelliklerine göre değerlendirirler. Duygusallık kavramı, destinasyonlar tarafından tüketiciye yüklenen duygu ve hisleri ifade etmektedir. Bu bileşen sayesinde turistlerin motivasyonu etki altına girmektedir (Lopes, 2011: 307).

\section{Gastronomi Kavramı ve Gastronomi İmajı}

Turizm sektörü açısından, destinasyon pazarlaması kapsamında gastronomi kavramı gerek yurt içinde gerekse yurt dışında hem pazarlama yapmak hem de hareketliliği arttırmak adına önemli bir rol oynamaktadır (Aydın, 2015: 9). Günümüzde gastronomi turistlerin seyahatlerinde tercih sebeplerinin yerinde önemli rol oynamaktadır. Ülkeleri ziyaret eden turistlerin tercihlerinin değişmesi, merak duygularının artması ve yeni tatlar arayışı içinde olmaları gastronomi turizminin nedenleri arasındadır (Aydın, 2015: 10).

Gastronomi kavramı, "güzel yemek pişirme, iyi yemek hakkındaki merakı ve mutfak kültürleri" olarak tanımlamaktadır (Aslan, 2010: 415). Gastronomi kavramının temel amac1; turistlerin yeme ve içme arzularını damak zevklerine hitap etmelerini sağlamak, destinasyonların içinde barındırdığ 1 kültür, tarih ve gastronomi becerilerini bir araya getirerek tüketicilere sunmaktır. Gastronomi kavramı, destinasyonlar için son derece önemli bir merak unsuru kazandırmaktadır. Turistlerin tatil amaçlı seçmiş oldukları destinasyonların nedenleri arasındadır. Destinasyonlarda yapılan gastronomi etkinlikleri turistleri seyahatleri sırasında farklı lezzetleri, gelenek ve görenekleri tanıması konusunda önemli rol üstlenir (Gökdeniz vd., 2015: 28).

Destinasyonların markalaşmasında yörelerin pazarlanmasının yanı sıra farklı turizm alternatifleriyle kentin cazibesinin arttırılması amaçlanmakta bu nedenle de yemek kültürünün farklılaştırılması ve farklılık arayan turistlere de hitap edebilen bir pazar oluşturma algısı oluşturmak ön plandadır. Şehirleri birinden ayıran özelliklerin ön plana çıkması ve şehre kazandırılan kimlik ve imaj kavramı giderek önem kazanmaya başlamıştır. Bunun en önemli nedeni ise ürün ve hizmetlerde olan rekabetin şehirlerarasında da giderek artmaya başlamasıdır (Serçeoğlu vd., 2016: 95). Gastronomi turizmi kavramı çoğu ülkede kolayca uygulanabilen bir turizm şeklidir. Ülkemiz yeme ve içme kültürü açısından oldukça çeşitlidir ve bu üstünlügünnü birçok alanda kullanabilmektedir (Özdemir, 2007). Gastronomi kavramı imaj oluşturmanın yanı 
Türk Turizm Araştırmaları Dergisi, 4(4): 3226-3248.

sıra turistlerde marka algısı oluşturarak gittikleri bölgelere yeniden seyahat etme isteği, çevresinde bulunan insanlara tavsiye etmelerini de sağlar. Bu sayede yöre yatırımclar içinde önemli bir yatırım olur. Böylece yörede yaşayan halkın kalkınmasını, alt yapısının gelişmesini, istihdam olanaklarının artması, gelenek ve göreneklerin daha dikkatli şekilde korunması gibi beraberinde pek çok olumlu gelişmelerde sağlayabilir (Kerimoğlu ve Çıracı, 2007; Çalışkan, 2013: 39). Gastronomi kavramı beraberinde marka kavramına da önemli bir katkı sağlamaktadır. Doğru yapılan gastronomi faaliyetleri, yörelerin kendilerini tanıtacak ürünleri turistlere tanıtma çalışmaları planlı bir şekilde uygulandığı takdirde marka haline gelmeye başlayacak ve bu destinasyonun bir imajı olmasına yardımcı olacaktır (Bucak ve Aracı, 2013: 205).

Gastronomi turizm hareketlerinin ve gastronomi turizmi konulu araştırmaların artması ile gastronomi tek başına bir çekicilik unsuru olarak görülmeye başlanmıştır. Destinasyonun imajını tek başına etkileme gücüne sahip olduğu da ifade edilmektedir (Choe ve Kim, 2018). Gastronomi imajı; ziyaretçilerin bir destinasyonun yiyecekleri, içecekleri, yiyecek içecek işletmeleri, yiyecek içecek kültürü ve yiyecek içecekle ilgili aktiviteleri hakkındaki inanç, duygu ve izlenimleri olarak tanımlanabilir. Gastronomi imajının bileşenlerinden olan en bilinen yiyecek ve içecekler destinasyonun mutfak kültürünü yansıtan önemli öğelerdir. Bir yiyecek veya içeceğin dünyanın pek çok yerinde bilindiği durumlar vardır. İtalya-pizza ve Japonya-Suşi eşleşmeleri örnek olarak gösterilebilir (Eren ve Çelik, 2017: 123).

\section{YÖNTEM}

\section{Araştırmanın Amacı, Önemi ve Sınırlılıkları}

Çalışmasının amacı, yerli turistlerin Bursa ilinin gastronomik marka imajına yönelik algılamalarının ortaya çıkarılmasıdır. Bu amaca ilaveten toplanacak veriler aracılı̆̆ıyla turistlerin Bursa'yı yeniden tercih etme ve başkalarına tavsiye etme gibi davranışsal niyetlerinin de ortaya çıkarılması mümkün olacaktır. Turistlerin destinasyonda yaşadığı olumlu deneyimler, bölgeyi yeniden ziyaret etmelerini ve çevrelerine de önermelerini sağlamaktadır. Rekabet ortamında turistlerin zihinlerinde oluşan bu imaj aynı hizmeti sunan rakiplere karşı bir üstünlük sağlamaktadır. Ürünler ve firmalar arasında rekabet olduğu gibi şehirlerarasında bir rekabet yaşanmaktadır. Bu yüzden tüketicilerin aklında oluşan destinasyon imajı oldukça önemli bir kavramdır. Bursa ili Osmanlı Devleti'ne başkentlik yaptığı dönemden itibaren köklü bir mutfak geçmişine sahiptir. Bursa ilinin oluşturduğu gastronomik marka imajı şehrin tanıtımı ve şehrin gastronomik turizm kapsamında gelişimi için oldukça önemlidir. Yapılan araştırmanın bazı sınırlılıkları bulunmaktadır. Araştırma için kullanılan anket formu, Bursa şehrinin ziyaret eden yerli turistler üzerinde uygulanmış, yabancı turistler ve yerel halk araştırmanın dışında kalmıştır. Yapılan bu araştırmanın bir diğer sınırlılığı ise araştırmanın belli zaman aralığ1 yani Şubat ve Mart aylarını kapsamasıdır. Çünkü bu aylar, Bursa İl Kültür ve Turizm Bakanlığı'ndan alınan veriler neticesinde yerli turistlerin ili en çok ziyaret ettiği aylar olarak belirlenmiştir. Araştırmada ortaya çıkan görüşler araştırma konusu ve kapsamı ile sınırlıdır.

\section{Araştırma Kapsamı}

$\mathrm{Bu}$ araştırmanın evreni, Bursa destinasyonunu ziyaret eden yerli turistlerdir. Fakat araştırmanın evreninin tamamına ulaşmak mümkün olmadığından, evreninden seçeceğimiz bir grup katılımcı (örneklem) ile çalışmak evreni temsil edecektir. Bu araştırma için kolayda örnekleme yöntemi tercih edilmiştir. Bursa İli Kültür ve Turizm Bakanlığı'ndan alınan bilgilere göre, Bursa ilini 2019 yılında 2.993.265 yerli turist ziyaret etmiştir. Bu rakama Turizm Bakanlığına yapılan ziyaret 


\section{Aydın YILMAZER, Ebru Ö. GÜVEN ve Kezban GÜLŞEN}

sonucunda ulaşılmıştır. Söz konusu evren büyüklüğü dikkate alınarak örneklem büyüklüğü +0,05 örnekleme hatası ile 384 iken, örnekleme hatasını azaltmak için örneklem büyüklügünün arttırılması gerektiği gerekçesi ile bu çalışmada yapılan yüz yüze anketlerden 601 geçerli anket sayısına ulaşılmıştır. Nicel yönteme sahip olan bu araştırmanın türü betimseldir. Çalışmada kullanılan anket formu daha önceki çalışmalar göz önüne alınarak (Kahraman, 2017), (Kargiglioğlu, 2015), ve (Yarış, 2014)' ün çalışmalarında kullandığı anketler üzerinde bazı düzenlemeler yapılarak elde edilmiştir. Analizlerde açıklayıcı istatistikler, t-testi, Anova, güvenilirlik testi, faktör analizi yöntemleri kullanılmıştır. Araştırmada kullanılan beşli Likert Ölçeği'nin yapılabilmesi için her ifadeye bir sayı verilmiştir. Buna göre "kesinlikle katılmıyorum" seçeneği 1, "katılmıyorum" seçeneği 2, "az katılıyorum" seçeneği 3, "katıllyorum" seçeneği 4, "tamamen katılıyorum" seçeneği için 5 rakamları kullanılmıştır. Katılımcılardan görüşlerini belirten seçenekler arasından işaretlenmesi istenmiştir.

\section{BULGULAR}

\section{Demografik Bulgular}

Araştırmaya katılanların demografik özellikleri incelendiğinde, örneklem sayısı olan 601 kişinin \%56,1'i kadınlardan oluşmaktadır. Bu kişilerin \%58,1'i 19-29 yaş aralığında yer almaktadır. Büyük bir çoğunluğu $(\% 61,5)$ üniversite eğitimi almıştır. Katılımcıların \%45,3'ü özel sektörde çalışmakta ve \%24,1'i de öğrencidir. Çalışmaya katılanların \%43,4'ünün aylık gelir düzeyi 2500 TL ve altında yer almaktadır (Tablo 1 ).

Tablo 1. Demografik Bulgular

\begin{tabular}{|c|c|c|c|c|c|c|c|}
\hline & & $\mathrm{n}$ & $\%$ & & & $\mathrm{n}$ & $\%$ \\
\hline \multirow[t]{2}{*}{ Cinsiyet } & Kadın & 337 & 56,1 & Meslek & Kamu & 46 & 7,7 \\
\hline & Erkek & 264 & 43,9 & & Özel Sektör & 272 & 45,3 \\
\hline \multirow[t]{5}{*}{ Yaş } & 18 ve altı & 40 & 6,7 & & Esnaf & 36 & 6,0 \\
\hline & $19-29$ & 349 & 58,1 & & Öğrenci & 145 & 24,1 \\
\hline & $30-40$ & 144 & 24,0 & & Ev Hanımı & 51 & 8,5 \\
\hline & $41-51$ & 49 & 8,2 & & Emekli & 18 & 3,0 \\
\hline & 52 ve üzeri & 19 & 3,2 & & Diğer & 33 & 5,5 \\
\hline \multirow[t]{5}{*}{ Eğitim } & Orta Öğretim & 61 & 10,1 & Gelir & 2500 ve altı & 261 & 43,4 \\
\hline & Lise & 170 & 28,3 & & $2501-3500$ & 158 & 26,3 \\
\hline & Önlisans & 139 & 23,1 & & $3501-4500$ & 75 & 12,5 \\
\hline & Lisans & 198 & 32,9 & & $4501-5500$ & 34 & 5,7 \\
\hline & Lisansüstü & 33 & 5,5 & & 5501 ve üzeri & 73 & 12,1 \\
\hline
\end{tabular}

Anket çalışmasına katılanların seyahat etme sıklıklarına bakıldığında, genellikle (\%30,3 oranında) yıldan 3'ten fazla seyahat ettikleri, tatil yeri tercihinde bölgedeki mutfak kültürü ve yiyecek-içecek çeşitliliğinin \%42,9 oranında ve Bursa iline seyahat etmede Bursa mutfağının ve yiyecek-içecek seçenekleri de \%45,8 oranında etkili olduğu saptanmıştır.

Demografik yapı ile seyahat etme sıklıkları, tatil yeri tercihi ve Bursa mutfağının seyahatlerine etkisi arasındaki ilişkinin tespiti için yapılan Ki-kare testleri sonucuna göre is, kadınların erkeklere göre daha fazla seyahat ettiği görülmüştür $\left(\chi^{2}=17,458: \mathrm{p}=0,002\right)$. Bununla birlikte, lisans mezunları $\left(\chi^{2}=53,000: p=0,000\right)$, özel sektör çalışanları $\left(\chi^{2}=48,085: p=0,002\right)$ ve 3500 TL altında gelire sahip olanlar $\left(\chi^{2}=42,849\right.$ : $\left.p=0,000\right)$ diğerlerine göre yılda en az 3 kez seyahat etmektedirler. Yaş farklılığı ile seyahat etme sıklığı arasında bir ilişki çıkmamıştır. Tatil yeri tercihinde bölgedeki mutfak kültürü ve yiyecek-içecek çeşitliliğinin etkisi ile demografik yapı farklılıkları arasında bir 
Türk Turizm Araştırmaları Dergisi, 4(4): 3226-3248.

ilişki tespit edilmemiştir ( $>>0,05)$. Benzer şekilde, Bursa iline seyahat etmede Bursa mutfağının ve yiyecek-içecek seçeneklerinin etkisi ile demografik yapı farklılıkları arasında bir ilişki tespit edilmemiştir $(p>0,05)$. Ayrıca, Bursa ilini ziyaret ederken kullanılan en popüler bilgi kaynağı olarak, çalışmaya katılanların \%28,1 oranıla en fazla "arkadaşlar ve akraba" tavsiyelerini değerlendirdiklerini belirtmişlerdir. Katılımcılar arkadaşlarının ve akrabalarının ziyaretleri sırasında turistik mekânları gezdiği ve yöresel yemekleri denediği gözlemlenmiştir. Bunu takip eden en yüksek tercih ise \%25,1 oran ile "bir önceki ziyaretim" olmuştur ifadesi almıştır. En önemli bilgi kaynakları içerisinde yer alan sosyal medya daha sonra yer almaktadır. Buna bakarak internet ve sosyal ve medya alanında yapılan tanıtımların yetersiz olduğunu söylemek mümkündür.

Anket sorularında, katılımcılara yöneltilen "Bursa mutfağı hakkında önceden bir bilginiz ya da bu kültürle ilgili fikriniz var mıdır?" sorusuna verilen yanıtlar şu şekilde sıralanmıştır. Buna göre Bursa mutfağı ve kültürü ile ilgili bilgiler \%46,6 oranıla en fazla "arkadaş, aile, eş, dost üzerinden" edinilmektedir. İkinci sırada ise "sosyal medya" yer almaktadır. Üçüncü sırada ise \%8,7 TV programları yer almaktadır. Bu oranlara bakıldığında ise Bursa Mutfağının yöresel lezzetlerinin tanıtımında gerçekleştirilen faaliyetlerin yetersiz olduğunu söylemek mümkündür. Bursa'ya yaptıkları seyahatte katılımcıların önemli bir bölümü (\%31, 8'i) Bursa'ya "arkadaş grubu ile bireysel" geldiğini belirtmiştir. Bununla birlikte "akraba ziyareti" için gelenler de $(\% 28,4)$ ikinci geliş nedenini oluşturmaktadır. Ankette yer alan "Bursa mutfağını daha önce hiç denememiş birine nasıl tarif edersiniz?" sorusuna karşılık katılımcıların genellikle olumlu bir tavır sergilediği gözlenmiştir. \%84,4'ü "olumlu" ve "tamamen olumlu" cevaplarını vermiştir. Gelen yerli turistlerin denedikten sonra yüksek oranda Bursa mutfağının yöresel yemeklerini beğendiklerini ve çevrelerine olumlu bir şekilde tarif ettiği gözlemlenmektedir. Bursa mutfağını daha önce hiç denenememiş birine değerlendirme ile demografik yapı farklılıkları arasında bir ilişki saptanamamıştır ( $p>0,05)$. Araştırmada, misafirlerin, mutfak kültürü ve yiyecek içecek çeşitliliği bakımından, Bursa şehrine gelmeden önceki beklentilerini karşılayıp karşılamadığı sorusuna, misafirlerin beklentilerinin \%80,2'sinin karşılandığı görülmektedir. Demografik farklılıklara göre değerlendirildiğinde ise, kadınların beklentisinin erkeklere göre daha fazla karşılandığ tespit edilmiştir $\left(\chi^{2}=10,785: p=0,029\right)$. Kadınların yemeklerdeki sunuma erkeklere oranla daha fazla önem verdiği gözlemlenmiştir. Diğer demografik farklılıklarla ilgili anlamlı bir ilişki bulunamamıştır $(p>0,05)$. Ankette yer alan "Bursa yemeklerini yeniden tatmak ister misiniz?" sorusuna katılımcıların geneli $\left(\% 92,7^{\prime}\right.$ si) olumlu yanıt vermişlerdir. Verilen yanıtlarla demografik yapı karşılaştırıldığında, kadınların $\left(\chi^{2}=11,283\right.$ : $\left.p=0,024\right)$ erkeklere göre Bursa yemeklerini yeniden tatma isteği daha fazladır. Katılımcıların cevapları Bursa yemeklerinin akılda kalıcı olduğunu göstermektedir. Diğer demografik farklılıklarla ilgili anlamlı bir ilişki bulunamamıştır $(\mathrm{p}>0,05)$.

Araştırmaya katılanların \%94,3'ü Bursa yöresine ait yemekleri ve mutfak kültürünü çevresine önerebileceğini belirtmektedir. Bursa yemeklerini ve mutfak kültürünü önerme ile demografik yapı farklılıkları arasında herhangi anlamlı bir ilişki tespit edilmemiştir ( $>00,05)$. Ankette, katılımcılardan "Bursa mutfağı denildiğinde akla gelen ilk 3 yiyecek" ismi istenmiştir. Verilen yanitlar değerlendirildiğinde, ilk üç sırada "İskender", "Kestane şekeri" ve "Pideli köfte" nin yer aldığı görülmektedir. Oluşturulan ölçeklerin değerlendirilmesine başlamadan önce bunların güvenilirlik yapıları gözden geçirilmiştir. Yapılan test sonucunda "Bursa yemeklerine ait düşünceler" ölçeğinde yer alan "Yeterince çeşitli değildir" maddesi güvenilirliği düşürdüğü için analizden çıkarılmıştır. Geri kalan maddeler üzerinde yapılan test ile güvenilirlik "yemeklere ait düşünceler" ölçeğinde \%81,5 (Cronbach Alfa $=0,815$ ) ve "gastronomik marka kimliği" ölçeğinde de \%92,9 (Cronbach Alfa=0,815) oranında çıkmıştır. İki ölçeğin de yüksek bir güvenilirliğe $(>0,80)$ sahip olduğu görülmektedir. 
Ölçeklerde yer alan ifadeler Likert tipinde hazırlandığı için bu sorulara verilen yanıtların incelenmesinde Faktör Analizinden yararlanılmıştır. Ancak, Faktör Analizinin yapılabilmesi için ilk önce örneklem yeterliliğine bakılmış ve verilerin faktör analizine uygun olup olmadıkları incelenmiştir. Bu inceleme için Kaiser-Meyer-Olkin (KMO) ve Bartlett Testleri sonuçlarına bakılmıştır. Uygulanacak faktör analizleri için kullanılan KMO testinin sonucunda "yemeklere ait düşünceler" ölçeğinde 0,921 olarak bulunmuştur. Bartlett Küresellik Testi sonucu da istatistiksel olarak anlamlı çıkmıştır $\left(\chi^{2}=4498,096: p=0,000<0,05\right)$. "Gastronomik marka kimliği" ölçeğinde de KMO Testi 0,921 ve Bartlett Küresellik Testi sonucu da anlamlı çıkmıştır $\left(\chi^{2}=5846,579: p=0,000<0,05\right)$. Dolayısıyla, analiz için örneklemin yeterli ve faktör analizine uygun olduğu sonucuna varılarak faktör analizine devam edilmiştir.

Tablo 2. Örneklem Yeterliliği ve Güvenilirlik Testi Sonuçları

\begin{tabular}{lll}
\hline \hline & $\begin{array}{l}\text { Yemeklere Ait } \\
\text { Düşünceler }\end{array}$ & $\begin{array}{l}\text { Gastronomik } \\
\text { Marka Kimliği }\end{array}$ \\
\hline Kaiser-Meyer-Olkin (KMO) Örneklem Yeterliliği & 0,875 & 0,921 \\
Serbestlik Derecesi & 120 & 105 \\
Bartlett Testi $\left(\chi^{2}\right)$ & 4498,096 & 5843,579 \\
Anlamlılık $(p)$ & 0,000 & 0,000 \\
Güvenilirlik (Cronbach Alfa) & 0,815 & 0,929 \\
\hline
\end{tabular}

Alt faktörleri elde etmek için uygulanan faktör analizinde, Varimax yöntemi uygulanarak iki ölçek grubu için de 2'şer alt faktör elde edilmiştir. "Yemeklere ait düşünceler" ölçeğinde yer alan alt faktörler toplam varyansın \%52,62'sini açlklayabilmektedir. Her faktörü oluşturan değişkenlerin istatistiksel değerleri ve her faktörün kendisine ait güvenilirlik seviyesi ile açıkladığı varyans oranı da Tablo 3'te gösterilmektedir. Buna göre, elde edilen ilk faktör olan "lezzet ve sunum" toplam varyansın \%34,84'ünü açılayabilmektedir. "İçerik" olarak isimlendirilen ikinci faktörün toplam varyans içindeki oranı ise \%17,78'dir. "Yemeklere ait düşünceler" ölçeğini oluşturan iki alt faktörün güvenirlikleri ise "lezzet ve sunum" için \%91,6 ve "içerik" için de \%74,4 olarak tespit edilmiştir (Tablo 3).

“Gastronomik marka kimliğii” ölçeğinde yer alan alt faktörler toplam varyansın \%62,23'ünü açılayabilmektedir. Her faktörü oluşturan değişkenlerin istatistiksel değerleri ve her faktörün kendisine ait güvenilirlik seviyesi ile açıkladığı varyans oranı da Tablo 'te gösterilmektedir. Buna göre, elde edilen ilk faktör olan "imaj" toplam varyansın \%51,06'sını açıklayabilmektedir. "Tanınırlık" olarak isimlendirilen ikinci faktörün toplam varyans içindeki oranı ise \%11,16 olarak tespit edilmiştir. "Gastronomik marka kimliği" ölçeğini oluşturan iki alt faktörün güvenirlikleri ise "imaj" için \%91,9 ve "tanınırlık" için de \%86,9 olarak bulunmuştur (Tablo 4). 
Türk Turizm Araştırmaları Dergisi, 4(4): 3226-3248.

Tablo 3. “Yemeklere Ait Düşünceler" Ölçeği İçin Faktör Analizi Sonuçları

\begin{tabular}{|c|c|c|c|c|}
\hline \multirow[b]{2}{*}{ Yemeklere Ait Düşünceler } & \multirow{2}{*}{$\begin{array}{l}\text { Faktör } \\
\text { Yükü }\end{array}$} & \multicolumn{2}{|c|}{ Temel Değerler } & \multirow[b]{2}{*}{$\mathrm{s}$} \\
\hline & & Medyan & Ort & \\
\hline \multicolumn{5}{|c|}{ Lezzet ve Sunum (Özdeğer = 5,575; Açılanan Varyans= \%34,84; Cronbach Alfa=0,916) } \\
\hline Bursa yemekleri lezzetlidir. & 0,842 & 5,0 & 4,34 & 0,88 \\
\hline İştah açıcıdır. & 0,834 & 4,0 & 4,28 & 0,90 \\
\hline Sunumları güzeldir & 0,802 & 4,0 & 4,18 & 0,89 \\
\hline Görüntüsü hoştur. & 0,793 & 4,0 & 4,21 & 0,90 \\
\hline Yemek çeşidi zengindir. & 0,762 & 4,0 & 4,02 & 1,01 \\
\hline Doyurucu ve sağlıklıdır. & 0,755 & 4,0 & 3,94 & 0,97 \\
\hline Porsiyonlar doyurucu ve göz doldurmaktadır & 0,733 & 4,0 & 3,95 & 1,05 \\
\hline Tekrar denemeye ve ziyaret etmeye değerdir. & 0,728 & 5,0 & 4,25 & 0,98 \\
\hline Herkesin damak tadına uygun ve ilgi çekicidir. & 0,728 & 4,0 & 3,83 & 1,05 \\
\hline \multicolumn{5}{|c|}{ İçerik (Özdeğer $=2,845 ;$ Açıklanan Varyans= $\% 17,78$; Cronbach Alfa $=0,744$ ) } \\
\hline Çok baharatlıdır. & 0,769 & 2,0 & 2,56 & 1,04 \\
\hline Fazla yağlıdır. & 0,758 & 3,0 & 2,92 & 1,10 \\
\hline Aşırı soğan ve sarımsaklıdır. & 0,696 & 2,0 & 2,50 & 1,10 \\
\hline Tatlıları hem çok yağlı hem de çok şekerlidir. & 0,669 & 3,0 & 2,82 & 1,16 \\
\hline Kalorisi oldukça yüksektir. & 0,533 & 4,0 & 3,63 & 1,06 \\
\hline Fazla etlidir. & 0,519 & 3,0 & 3,30 & 1,16 \\
\hline Yöresel lezzetler sunan işletmeler çok pahalıdır. & 0,436 & 4,0 & 3,48 & 1,16 \\
\hline
\end{tabular}

Açıklanan varyans $=\% 52,62$

Elde edilen faktörlerin iç tutarlılıkları analizleri t-test ile kontrol edilmiştir Yapılan testler sonucunda tüm faktörlerin kendi içlerinde istatistiksel olarak anlamlı seviyede farklılaştıkları tespit edilmiştir $(p<0,05)$. Tablo 5 'de yer verilmiştir. Bununla birlikte alt faktörlerin korelasyon değerleri de belirtilmiştir. Buna göre, yemeklere ait düşünceler içerisinde "lezzet ve sunum" ile "içerik" arasında anlamlı bir ilişki çıkmamıştır ( $\mathrm{r}=0,050$ : $\mathrm{p}=0$,217). Ancak, gastronomik marka kimliği içerisinde "imaj" ile "tanınırlık" arasında pozitif yönlü anlamlı bir ilişki tespit edilmiştir $(\mathrm{r}=0,647: \mathrm{p}=0,000)$. Başka bir ifadeyle, gastronomik imajda oluşan bir yükselme tanınırlığı da artırmaktadır. Tablo 5'de yer verilmiştir. 
Aydın YILMAZER, Ebru Ö. GÜVEN ve Kezban GÜLŞEN

Tablo 4. “Gastronomik Marka Kimliği” Ölçeği İçin Faktör Analizi Sonuçları

\begin{tabular}{|c|c|c|c|c|}
\hline \multirow{2}{*}{ Gastronomik Marka Kimliği } & \multirow{2}{*}{$\begin{array}{l}\text { Faktör } \\
\text { Yükü }\end{array}$} & \multicolumn{2}{|c|}{ Temel Değerler } & \multirow[b]{2}{*}{$\mathrm{s}$} \\
\hline & & Medyan & Ort & \\
\hline \multicolumn{5}{|c|}{ İmaj (Özdeğer = 7,659; Açıklanan Varyans= \%51,06; Cronbach Alfa=0,919) } \\
\hline $\begin{array}{l}\text { Şehre bir marka imajı oluşturmada Bursa mutfağı } \\
\text { önemli bir unsurdur. }\end{array}$ & 0,850 & 4,0 & 4,00 & 0,98 \\
\hline Bursa mutfağı şehrin marka algısını arttırmaktadır. & 0,816 & 4,0 & 4,02 & 1,01 \\
\hline Bursa mutfağı şehir turizmi için önemlidir. & 0,808 & 4,0 & 4,17 & 0,99 \\
\hline $\begin{array}{l}\text { Bursa'da bulunan yöresel yemekler denemeye ve } \\
\text { satın almaya değerdir. }\end{array}$ & 0,785 & 4,0 & 4,14 & 0,89 \\
\hline $\begin{array}{l}\text { Bursa'ya gelen ziyaretçi sayısının artmasında Bursa } \\
\text { mutfağı önemlidir. }\end{array}$ & 0,770 & 4,0 & 3,95 & 1,01 \\
\hline $\begin{array}{l}\text { Bursa mutfağı ülke çapında bilinen yöresel lezzetlere } \\
\text { sahiptir. }\end{array}$ & 0,694 & 4,0 & 3,98 & 0,99 \\
\hline $\begin{array}{l}\text { Bursa'da yerel mutfakları sunan yeme- içme } \\
\text { işletmeleri diğer işletmelere göre daha fazla talep } \\
\text { edilmektedir. }\end{array}$ & 0,651 & 4,0 & 3,79 & 0,98 \\
\hline Bursa mutfağı bir marka değerine sahiptir. & 0,639 & 4,0 & 3,90 & 1,04 \\
\hline $\begin{array}{l}\text { Tatil dönüşünde veya seyahatlerimde akrabalarıma } \\
\text { ve evime götürmek için yöresel lezzetlerden satın } \\
\text { alırım. }\end{array}$ & 0,559 & 4,0 & 3,97 & 1,04 \\
\hline \multicolumn{5}{|c|}{ Tanınırlık (Özdeğer = 1,675; Açıklanan Varyans= \%11,16; Cronbach Alfa=0,869) } \\
\hline $\begin{array}{l}\text { Bursa mutfak kültürünü tanitacak etkinlikler } \\
\text { yeterlidir. }\end{array}$ & 0,867 & 3,0 & 3,13 & 1,20 \\
\hline $\begin{array}{l}\text { Bursa Mutfak kültürünün korunması ve gelecek } \\
\text { nesillere aktırılması için yapılan tanıtımlar yeterlidir. }\end{array}$ & 0,818 & 3,0 & 3,21 & 1,19 \\
\hline Bursa'nın yöresel lezzetleri yeterince tanitılmaktadır. & 0,768 & 3,0 & 3,36 & 1,20 \\
\hline $\begin{array}{l}\text { Şehirde yapılan gastronomi aktiviteleri sayesinde } \\
\text { Bursa mutfağı tanınmaya başlamıştır. }\end{array}$ & 0,661 & 4,0 & 3,49 & 1,11 \\
\hline $\begin{array}{l}\text { Yerel lezzetler sunan işletmeler de çalışanlar güler } \\
\text { yüzlü ve naziktir. }\end{array}$ & 0,594 & 4,0 & 3,84 & 0,95 \\
\hline $\begin{array}{l}\text { Yerel lezzetler sunan esnaf oldukça güler yüzlü ve } \\
\text { naziktir. }\end{array}$ & 0,565 & 4,0 & 3,85 & 0,97 \\
\hline
\end{tabular}

Tablo 5. Faktörlerin İç Analizleri

\begin{tabular}{lllllllll}
\hline \hline & & Ort & $\mathrm{s}$ & $\mathrm{t}$ & $\mathrm{sd}$ & $\mathrm{p}$ & $\mathrm{r}$ & $\mathrm{p}$ \\
\hline Yemeklere Ait & Lezzet ve & 4,11 & 0,74 & & & & & \\
Düşünceler & Sunum & & & 26,594 & 600 & 0,000 & 0,050 & 0,217 \\
& İçerik & 3,03 & 0,70 & & & & & \\
Gastronomik & İmaj & 3,99 & 0,78 & & & & & \\
Marka Kimliği & Tanınırlık & 3,48 & 0,86 & 18,078 & 600 & 0,000 & 0,647 & 0,000 \\
& & & & & & & \\
\hline
\end{tabular}


Türk Turizm Araştırmaları Dergisi, 4(4): 3226-3248.

Yemeklere ait düşünceler içerisinde "lezzet ve sunum" faktörü $(4,11 \pm 0,74)$ "içerik" faktörüne $(3,03 \pm 0,70)$ daha fazla önemsenmektedir. Bununla birlikte, gastronomik marka kimliği olarak "imaj" faktörüne $(3,99 \pm 0,78)$ "tanınırlık" faktörüne göre $(3,48 \pm 0,86)$ daha çok önem verilmiştir. Şekil 1'de yer verilmiştir

Şekil 1. Faktörlerin Birbirine Göre Durumu

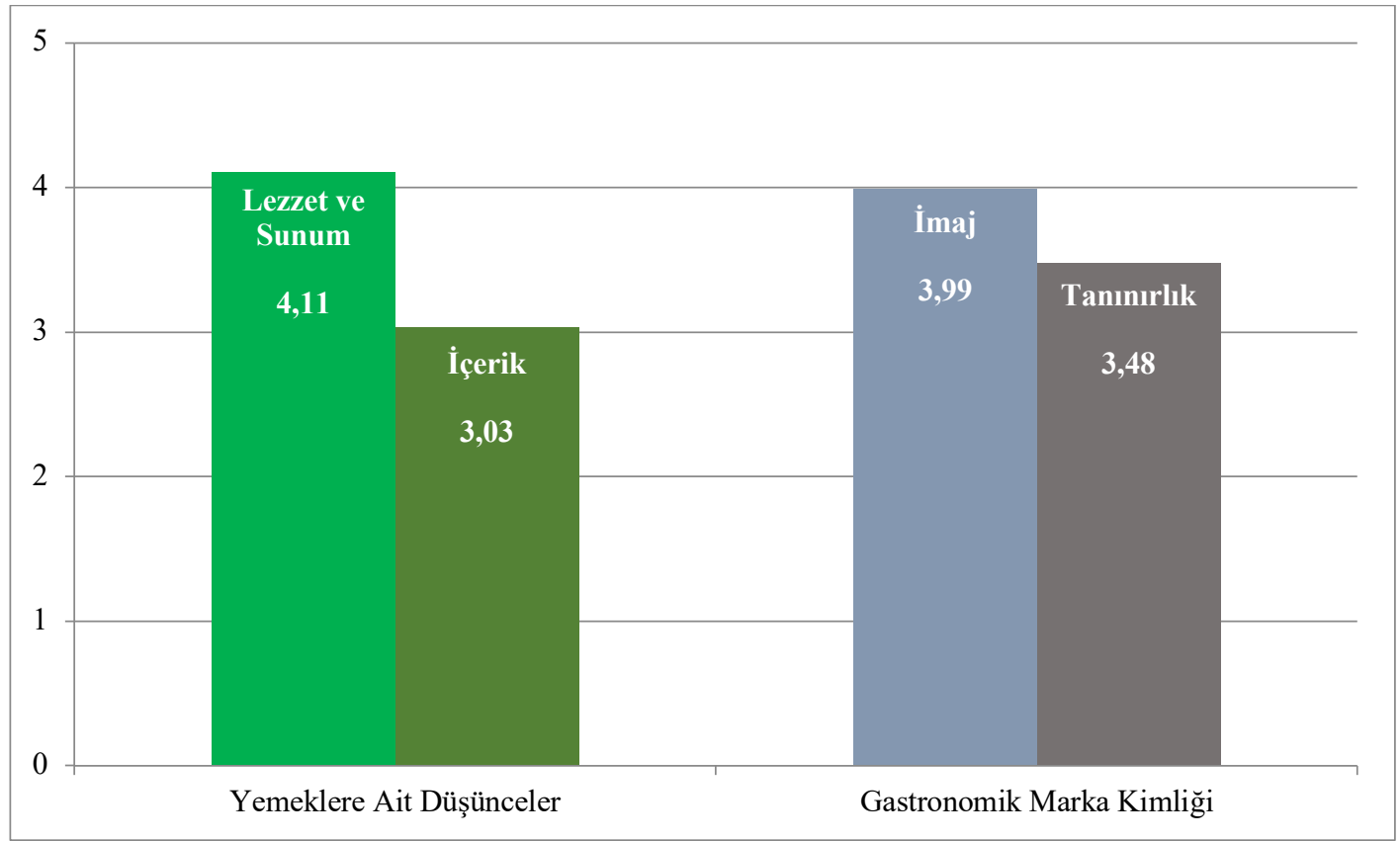

\section{Demografik Yapı ile Faktörlerin Karşılaştırılması}

Demografik yapının "yemeklere ait düşünceler" ve "gastronomik marka kimliğii"ni oluşturan faktörlere göre oluşturduğu farklılaşmaların belirlenebilmesi için t-test ve Anova testi'nden yararlanılmıştır. Anova analizi sonucunda ortaya çıkan farklılığın derinlemesine incelenmesinde ise Post-hoc testlerden Tukey Test kullanılmıştır.

\section{Cinsiyet}

Çalışmaya katılan kişilerin cinsiyetlerine göre oluşturulan faktörlere verdikleri değerler Tablo 6'da ve Şekil 2'de belirtilmiştir. Cinsiyet farklılığının "yemeklere ait düşünceler" faktörler arasındaki ilişkinin belirlenebilmesi amacıyla yapılan testte ortaya çıan sonuçlara yemeklere ait düşünceler bağlamında lezzet ve sunum değişkeni cinsiyetlere göre farklılık göstermektedir. Bu kapsamda "lezzet ve sunum"a, kadınların erkeklere göre daha fazla önem verdikleri görülmüştür $(p=0,005)$. "Gastronomik marka kimliğinde de kadınlar erkeklere göre "imaj" konusuna daha fazla önem vermektedirler $(\mathrm{p}=0,001)$. 
Şekil 2. Cinsiyet Farklılığının Faktörlere Göre Dağılımı

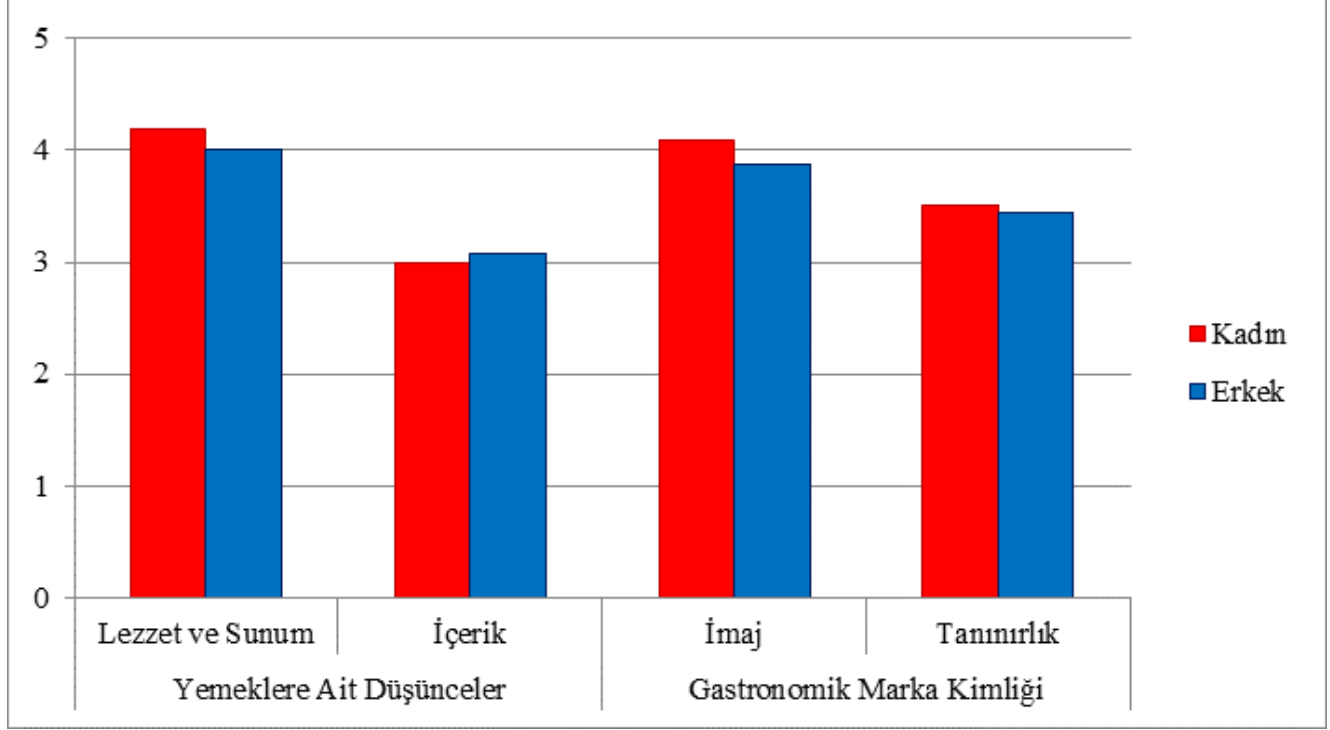

Tablo 6. Cinsiyet Farklılığının Faktörlerle İlişkisi

\begin{tabular}{|c|c|c|c|c|c|c|}
\hline & & Cinsiyet & Ort & $\mathrm{s}$ & $\mathrm{t}$ & $p$ \\
\hline \multirow{4}{*}{$\begin{array}{l}\text { Yemeklere Ait } \\
\text { Düşünceler }\end{array}$} & \multirow{2}{*}{$\begin{array}{l}\text { Lezzet ve } \\
\text { Sunum }\end{array}$} & Kadın & 4,19 & 0,70 & \multirow{2}{*}{2,804} & \multirow{2}{*}{0,005} \\
\hline & & Erkek & 4,02 & 0,78 & & \\
\hline & \multirow{2}{*}{ İçerik } & Kadın & 2,99 & 0,71 & \multirow{2}{*}{$-1,584$} & \multirow{2}{*}{0,114} \\
\hline & & Erkek & 3,08 & 0,68 & & \\
\hline \multirow{4}{*}{$\begin{array}{l}\text { Gastronomik } \\
\text { Marka Kimliği }\end{array}$} & \multirow{2}{*}{ İmaj } & Kadın & 4,08 & 0,71 & \multirow{2}{*}{3,402} & \multirow{2}{*}{0,001} \\
\hline & & Erkek & 3,87 & 0,83 & & \\
\hline & \multirow{2}{*}{ Tanınırlık } & Kadın & 3,51 & 0,82 & \multirow{2}{*}{0,920} & \multirow{2}{*}{0,358} \\
\hline & & Erkek & 3,44 & 0,91 & & \\
\hline
\end{tabular}

Yaş

Anketin üçüncü ve dördüncü bölümü iki başlık altında gruplandırılmıştır. Değerlere bakıldığında 18 yaş ve altı grubun lezzet, sunum ve içeriğe diğer yaş gruplarına nazaran biraz daha fazla önem verdiği görülmektedir. Fakat değerler birbirine oldukça yakındır. Bu yüzden yaş gruplarının faktörler üzerinde bir farklılık yaratmadığı gözlemlenmiştir. Araştırmaya katılan kişilerin yaş farklılıklarına göre faktörlere verdikleri değerler Tablo 7'de ve Şekil 3'te gösterilmiştir. Yapılan testler sonucunda hiçbir yaş grubunun faktörlerde herhangi bir farklılaşma göstermediği tespit edilmiştir $(\mathrm{p}>0,05)$. 
Türk Turizm Araştırmaları Dergisi, 4(4): 3226-3248.

Şekil 3. Yaş Farklılığının Faktörlere Göre Dağılımı

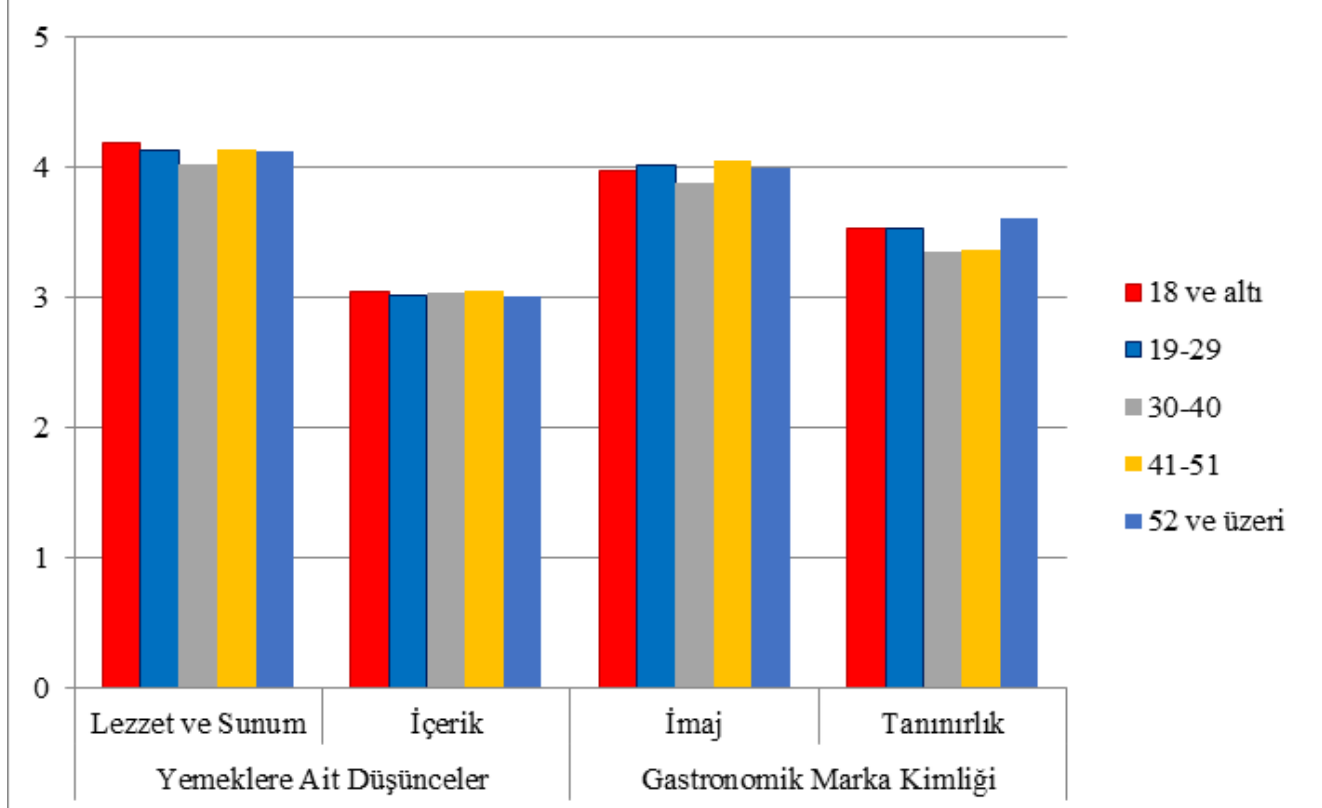

Tablo 7. Yaş Farklılı̆̆ının Faktörler ile İlişkisi

\begin{tabular}{|c|c|c|c|c|c|c|}
\hline & & Yaş & Ort & $\mathrm{s}$ & $\mathrm{F}$ & $p$ \\
\hline \multirow{10}{*}{$\begin{array}{l}\text { Yemeklere Ait } \\
\text { Düşünceler }\end{array}$} & \multirow{5}{*}{$\begin{array}{l}\text { Lezzet ve } \\
\text { Sunum }\end{array}$} & 18 ve altı & 4,20 & 0,76 & \multirow{5}{*}{0,783} & \multirow{5}{*}{0,536} \\
\hline & & $19-29$ & 4,13 & 0,73 & & \\
\hline & & $30-40$ & 4,02 & 0,79 & & \\
\hline & & $41-51$ & 4,15 & 0,71 & & \\
\hline & & 52 ve üzeri & 4,13 & 0,76 & & \\
\hline & \multirow{5}{*}{ İçerik } & 18 ve altı & 3,05 & 0,79 & \multirow{5}{*}{0,054} & \multirow{5}{*}{0,995} \\
\hline & & $19-29$ & 3,02 & 0,69 & & \\
\hline & & $30-40$ & 3,04 & 0,70 & & \\
\hline & & $41-51$ & 3,06 & 0,69 & & \\
\hline & & 52 ve üzeri & 3,01 & 0,74 & & \\
\hline \multirow{10}{*}{$\begin{array}{l}\text { Gastronomik } \\
\text { Marka Kimliği }\end{array}$} & \multirow{5}{*}{ İmaj } & 18 ve alt & 3,97 & 0,88 & \multirow{5}{*}{0,867} & \multirow{5}{*}{0,484} \\
\hline & & $19-29$ & 4,02 & 0,76 & & \\
\hline & & $30-40$ & 3,89 & 0,81 & & \\
\hline & & $41-51$ & 4,05 & 0,73 & & \\
\hline & & 52 ve üzeri & 3,99 & 0,72 & & \\
\hline & \multirow{5}{*}{ Tanınırlık } & 18 ve altı & 3,54 & 0,94 & \multirow{5}{*}{1,349} & \multirow{5}{*}{0,251} \\
\hline & & $19-29$ & 3,53 & 0,84 & & \\
\hline & & $30-40$ & 3,36 & 0,86 & & \\
\hline & & $41-51$ & 3,37 & 0,90 & & \\
\hline & & 52 ve üzeri & 3,61 & 1,03 & & \\
\hline
\end{tabular}

\section{Eğitim Düzeyi}

Çalışmaya katılan kişilerin eğitim düzeylerinin oluşturulan faktörlere göre dağılımı ve istatistiki değerleri Tablo 8'de ve Şekil 4'te belirtilmiştir. Yapılan analizler sonucunda eğitim düzeyi farklılığının sadece "yemeklere ait düşünceler" içerisinde "lezzet ve sunum" faktörü ile ilişkisi 
olduğu görülmüştür $(p=0,001)$. Farklılığın hangi eğitim düzeyleri arasında olduğunun belirlenmesi amacıyla yapılan Post-hoc test sonucunda lise mezunlarının lisansüstü mezunlarına göre ve ön lisans mezunlarının da lisans mezunlarına göre "lezzet ve sunum"a daha fazla önem verdikleri belirlenmiştir.

Şekil 4. Eğitim Düzeyi Farklılığının Faktörlere Göre Dağılımı

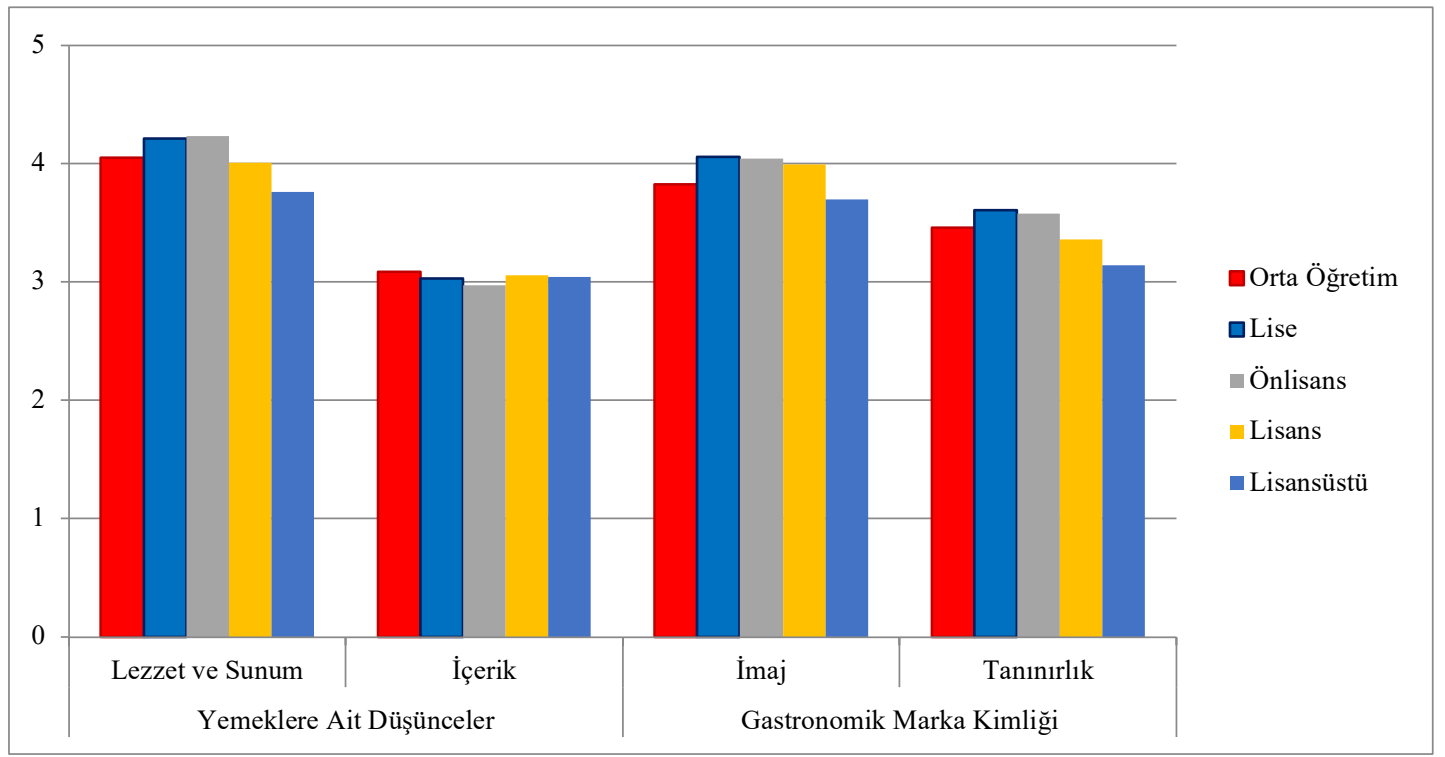

Tablo 8. Eğitim Düzeyi Farklılığının Faktörler ile İlişkisi

\begin{tabular}{|c|c|c|c|c|c|c|c|}
\hline & & Eğitim & Ort & $\mathrm{s}$ & $\bar{F}$ & $p$ & Fark \\
\hline \multirow{10}{*}{$\begin{array}{l}\text { Yemeklere Ait } \\
\text { Düşünceler }\end{array}$} & & $\begin{array}{l}\text { Orta } \\
\text { Öğretim }\end{array}$ & 4,05 & 0,96 & \multirow{5}{*}{4,816} & \multirow{5}{*}{0,001} & \\
\hline & Lezzet ve & Lise & 4,22 & 0,69 & & & $2-5$ \\
\hline & \multirow[t]{4}{*}{ Sunum } & Önlisans & 4,24 & 0,69 & & & $3-4$ \\
\hline & & Lisans & 4,01 & 0,72 & & & \\
\hline & & Lisansüstü & 3,76 & 0,77 & & & \\
\hline & & $\begin{array}{l}\text { Orta } \\
\text { Öğretim }\end{array}$ & 3,08 & 0,82 & & & \\
\hline & \multirow{4}{*}{ İçerik } & Lise & 3,03 & 0,77 & \multirow{4}{*}{0,382} & \multirow{4}{*}{0,822} & \\
\hline & & Önlisans & 2,97 & 0,70 & & & \\
\hline & & Lisans & 3,06 & 0,60 & & & \\
\hline & & Lisansüstü & 3,05 & 0,65 & & & \\
\hline \multirow{10}{*}{$\begin{array}{l}\text { Gastronomik } \\
\text { Marka Kimliği }\end{array}$} & \multirow{5}{*}{ İmaj } & $\begin{array}{l}\text { Orta } \\
\text { Öğretim }\end{array}$ & 3,83 & 0,91 & \multirow{5}{*}{2,298} & \multirow{5}{*}{0,058} & \\
\hline & & Lise & 4,05 & 0,71 & & & \\
\hline & & Önlisans & 4,04 & 0,79 & & & \\
\hline & & Lisans & 3,99 & 0,74 & & & \\
\hline & & Lisansüstü & 3,70 & 0,92 & & & \\
\hline & \multirow{5}{*}{ Tanınırlık } & $\begin{array}{l}\text { Orta } \\
\text { Öğretim }\end{array}$ & 3,46 & 0,96 & \multirow{5}{*}{3,640} & \multirow{5}{*}{0,006} & \multirow{5}{*}{$2-4$} \\
\hline & & Lise & 3,61 & 0,87 & & & \\
\hline & & Önlisans & 3,58 & 0,78 & & & \\
\hline & & Lisans & 3,36 & 0,86 & & & \\
\hline & & Lisansüstü & 3,15 & 0,88 & & & \\
\hline
\end{tabular}


Türk Turizm Araştırmaları Dergisi, 4(4): 3226-3248.

\section{Meslek}

Çalışmaya katılan kişilerin meslek farklılıklarının faktörler üzerindeki ilişkisinin belirlenmesi amacıyla ortaya çıkarılan değerler Tablo 9'da ve Şekil 5'te gösterilmektedir.

Şekil 5. Meslek Farklılığının Faktörlere Göre Dağılımı

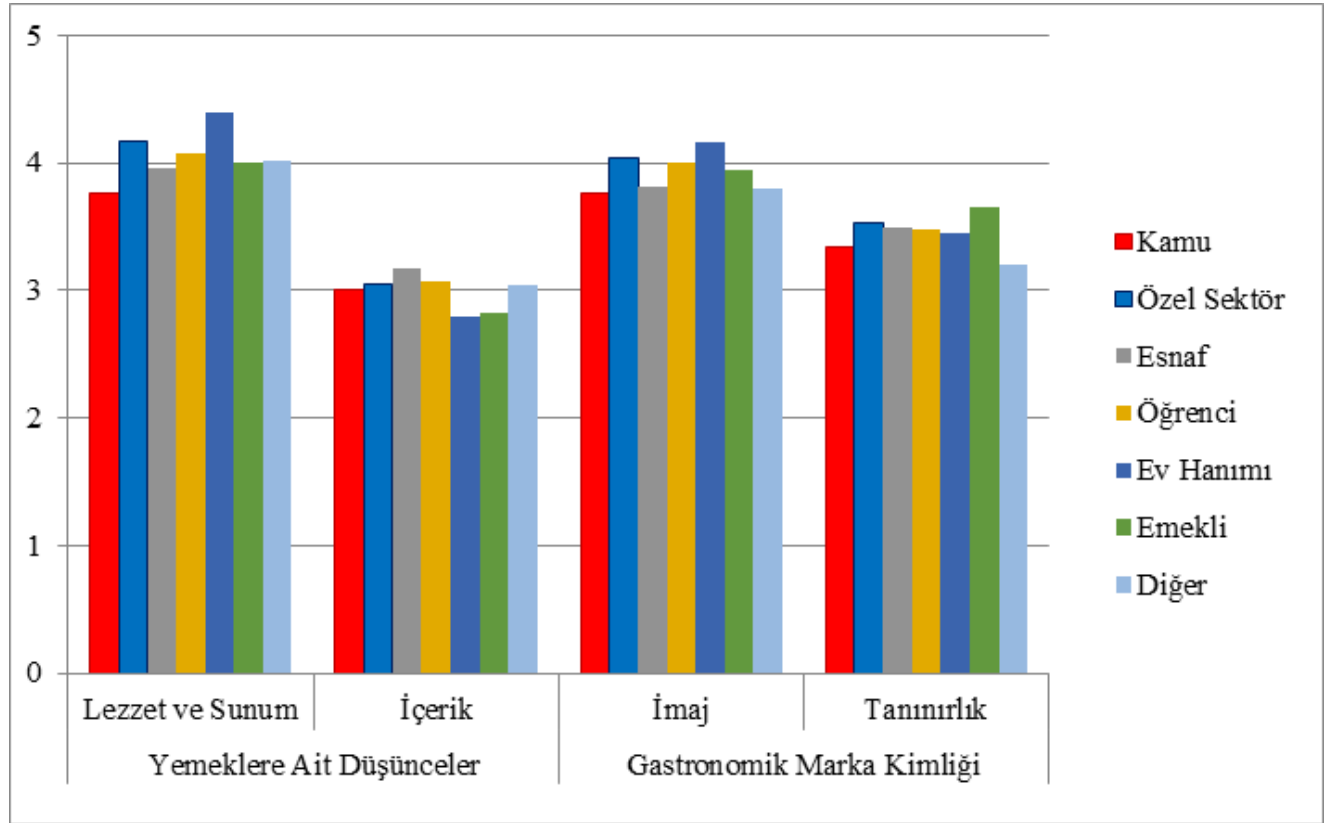

Tablo 9. Meslek Farklılığının Faktörler Üzerindeki İlişkisi

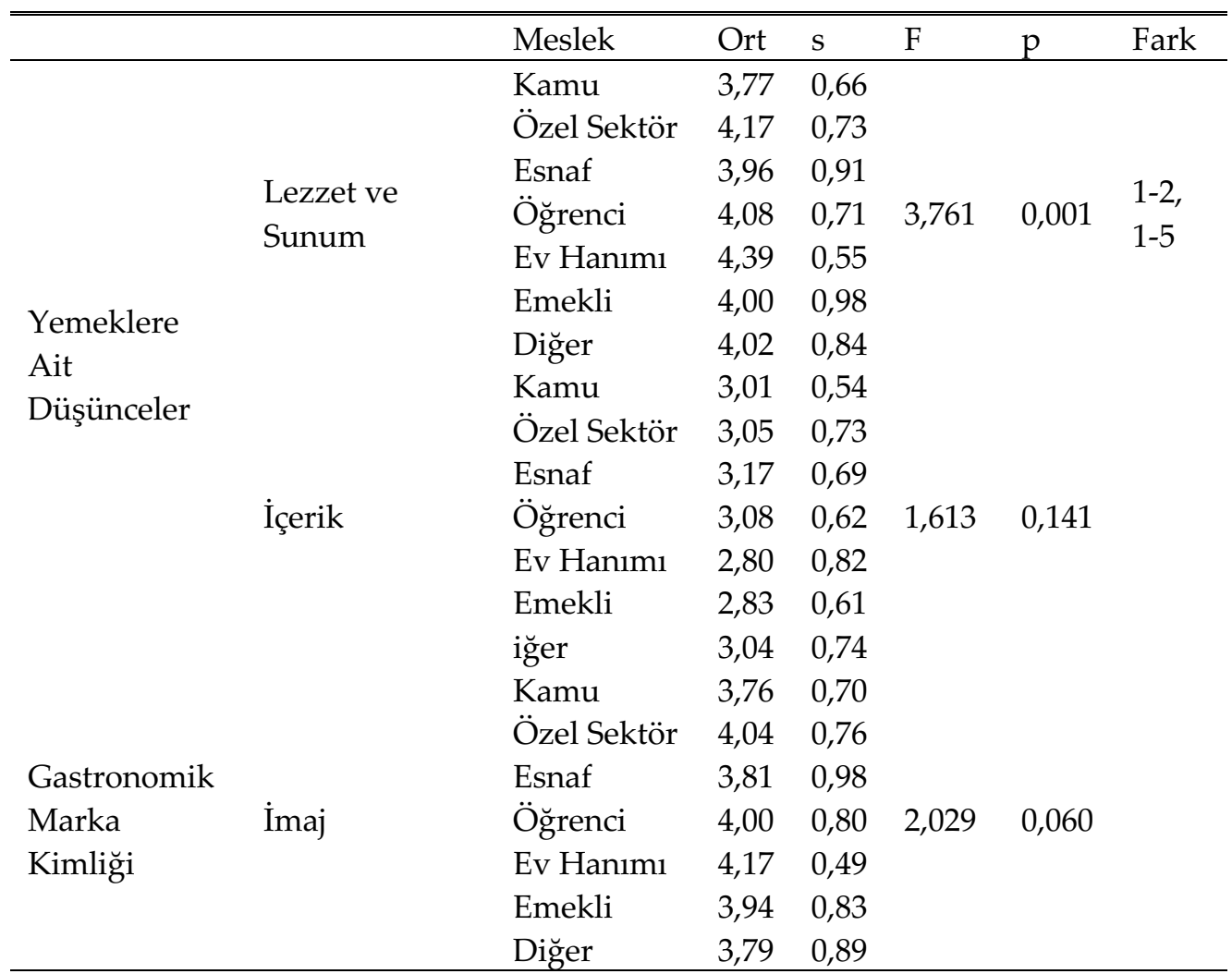




\section{Aydın YILMAZER, Ebru Ö. GÜVEN ve Kezban GÜLŞEN}

Sadece "lezzet ve sunum" alt faktöründe ortaya çıan meslekler arası farklılık $(p=0,001)$ için de Post-hoc testine başvurulmuştur. Böylece hangi meslek gruplarının birbirlerine göre daha fazla farklılaştığı tespit edilebilecektir. Test sonucuna göre özel sektör çalışanları kamuda çalışanlara göre ve ev hanımları da kamuda çalışanlara göre "lezzet ve sunum"a daha fazla önem vermektedirler. Diğer alt faktörlerde ortaya çıkan meslekler arası farklılıklar istatistiki olarak anlamlı bir değer ortaya çıkarmamışlardır ( $p>0,05)$.

\section{Gelir Seviyesi}

Kişilerin aylık gelir seviyelerinin faktörler üzerindeki farklılaşmalarına dair değerler Tablo 10' da ve Şekil 6 'da belirtilmiştir. Yapılan ANOVA testleri sonucunda gelir seviyesinin faktörlerde herhangi bir farklılaşma göstermediği tespit edilmiştir ( $p>0,05)$.

Şekil 6. Gelir Farklılığının Faktörlere Göre Dağılımı

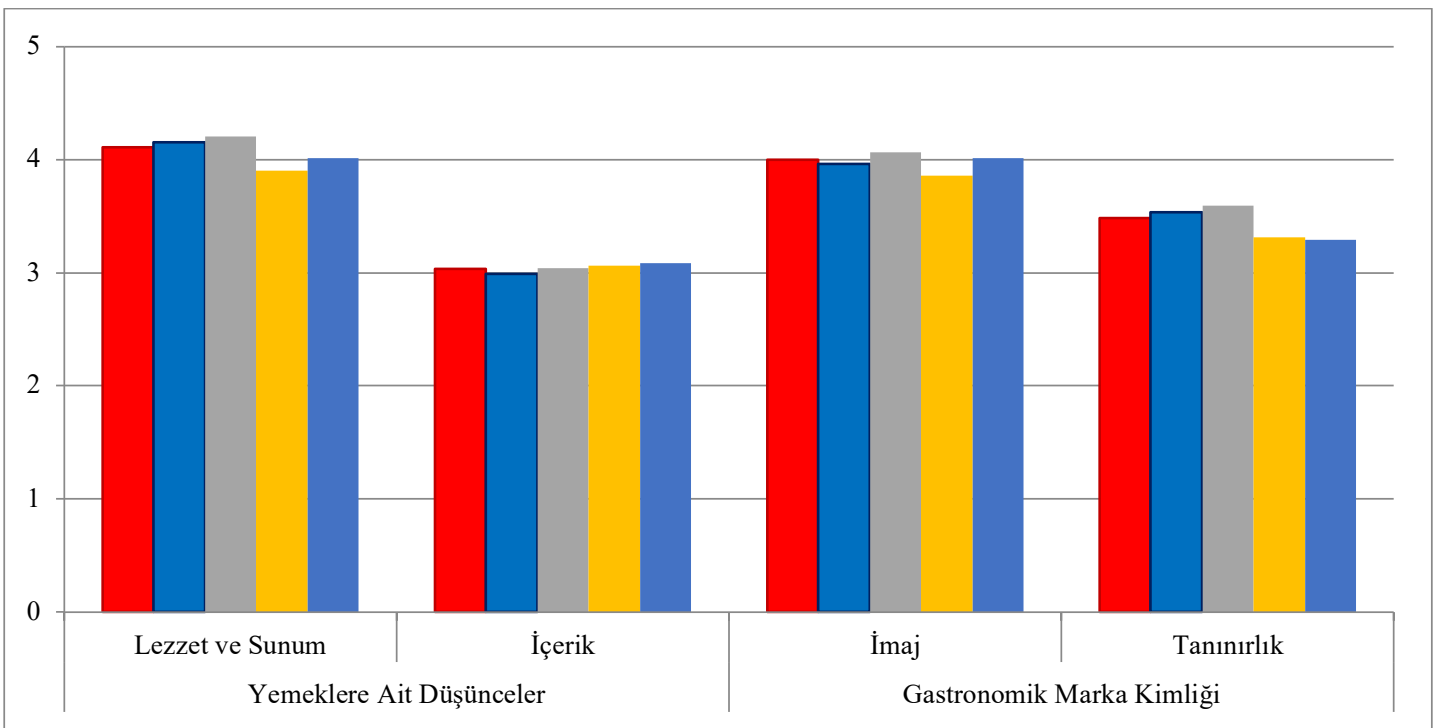

Araştırma bulguları özetlenirse; yapılan Bursa ilini ziyaret eden yerli turistlerin, demografik özellikleri incelendiğinde araştırmaya katılan katılımcıların çoğunluğunu kadınların oluşturduğu, katılımcıların yaş aralıklarında ise en fazla 19-29 yaşa aralığında olduğu, yüksek oranda üniversite eğitimi aldığı, orta gelir seviyesine sahip turistlerin tercih ettiği söylemek mümkündür. Ayrıca, Bursa iline geldiklerinde yemek kültürüne dair beklentilerin çok yüksek oranda karşılandığı, "lezzet ve sunum"a, kadınların erkeklere göre daha fazla önem verdikleri, eğitim düzeylerine göre anlamlı farklılık olduğu gelir düzeyleri ve yaş grubuna ait katılımcıların yaşları ile yöresel yemeklere ait düşünceler arasında bir farklılık görülmediği anlaşılmaktadır. 
Türk Turizm Araştırmaları Dergisi, 4(4): 3226-3248.

Tablo 10. Gelir Farklılığının Faktörler İlişkisi

\begin{tabular}{|c|c|c|c|c|c|c|}
\hline & & Gelir & Ort & $\mathrm{s}$ & $\mathrm{F}$ & $\mathrm{p}$ \\
\hline & & 2500 ve alt1 & 4,11 & 0,74 & & \\
\hline & & $2501-3500$ & 4,15 & 0,77 & & \\
\hline & Lezzet ve Sunum & $3501-4500$ & 4,21 & 0,63 & 1,422 & 0,225 \\
\hline & & $4501-5500$ & 3,90 & 0,73 & & \\
\hline Yemeklere Ait & & 5501 ve üzeri & 4,01 & 0,79 & & \\
\hline \multirow[t]{9}{*}{ Düşünceler } & & 2500 ve alt1 & 3,04 & 0,72 & & \\
\hline & & $2501-3500$ & 2,99 & 0,69 & & \\
\hline & İçerik & $3501-4500$ & 3,04 & 0,70 & 0,251 & 0,909 \\
\hline & & $4501-5500$ & 3,06 & 0,67 & & \\
\hline & & 5501 ve üzeri & 3,08 & 0,64 & & \\
\hline & & 2500 ve altı & 4,00 & 0,77 & & \\
\hline & & $2501-3500$ & 3,96 & 0,82 & & \\
\hline & İmaj & $3501-4500$ & 4,06 & 0,72 & 0,475 & 0,754 \\
\hline & & $4501-5500$ & 3,86 & 0,73 & & \\
\hline Gastronomik & & 5501 ve üzeri & 4,01 & 0,75 & & \\
\hline \multirow[t]{5}{*}{ Marka Kimliğgi } & & 2500 ve altı & 3,49 & 0,84 & & \\
\hline & & $2501-3500$ & 3,54 & 0,87 & & \\
\hline & Tanınırlık & $3501-4500$ & 3,59 & 0,88 & 1,706 & 0,147 \\
\hline & & $4501-5500$ & 3,31 & 0,78 & & \\
\hline & & 5501 ve üzeri & 3,29 & 0,91 & & \\
\hline
\end{tabular}

\section{TARTIŞMA, SONUÇ ve ÖNERILER}

Ülkeler turizm ile ilgili sahip oldukları kaynakları tanıtmada içerisinde barındırdığı doğal kaynakların yanı sıra sahip oldukları yemek kültürlerini de ön plana çıkartmaktadır. İnsanların artan merakları ile birlikte gelişmeye başlayan gastronomi bilimi, ülkelerinde bu alana yönelik yatırım yapmaya başlamalarına neden olmuştur. $\mathrm{Bu}$ doğrultuda gastronomi turizmi destinasyonu ziyaret eden turistlerin o destinasyonun mutfak kültürünü daha iyi tanımak ve yöre yemeklerinin yapılışı hakkında fikir sahibi olmak, tadına bakmak gibi kavramlardan yola çıarak gelişen alternatif bir turizm çeşidi haline gelmektedir. Zengin mutfak kültürüne sahip Bursa şehri kuruluşundan itibaren gerek coğrafi yapısı gerekse barındırdığı kültürel çeşitlilikleri bakımından oldukça önem arz eden bir destinasyondur. Ülkemiz de gerek tarihi gerekse kendine has gelişen mutfak kültürü ile gastronomi turizmi için önemli bir cazibe merkezidir. Yapılan pek çok araştırma da ülkemizin dünyaca ünü olan bir mutfak kültürüne sahip olduğunu düşünen turist sayısı oldukça fazladır. Yapılan araştırmada elde edilen bulgularda Bursa yöresine ait yemeklerin büyük çoğunluğunun unutulduğu anlaşılmıştır. Tanıtımı yapılan ürünlerin akılda kalıcllığının yüksek olduğu gözlemlenmiştir. Gelen turistlerin şehrin hem tarihi ve doğal güzelliklerini çok beğendiği gözlemlenmiştir. Elde edilen bulgular neticesinde turistlerin Bursa ilini yeniden ziyaret etmek istedikleri, çevrelerine olumlu bir şekilde önerdiklerini hatta birçoğunun arkadaş ve eş, dost tavsiyesi ile geldiği görülmektedir. Bu verilerin sonucunda Bursa ilinin hem tarihi ve doğal açıdan dikkat çekici bir destinasyon olduğunu söylemek mümkündür. Bursa ilinin bu çekicilik unsurlarını en verimli şekilde pazarlaması şehre bir marka kimliği kazandıracaktır. Ancak yapılan tanıtımlarının yetersiz kaldığını katılımcıların cevapları doğrultusunda söylemek mümkündür. Sayılan öneriler doğrultusunda Bursa ili mutfağını tanıtacak çalışmalar yöreye özgü lezzetlerin gastronomi turizmine katkı sağlaması, turistlerin yeniden ziyaret etmesini sağlayacak pazarlama çalışmalarının yapılması ve gastronomik bir imaj yaratmak açısından önemli derece katkı sağlanması düşünülmektedir. 
Araştırma kapsamında yapılan Bursa ilini ziyaret eden yerli turistlerin demografik özellikleri incelendiğinde araştırmaya katılan katılımcıların çoğunluğunu kadınların oluşturduğunu söylemek mümkündür. İli ziyaret eden katılımcıların yaş aralıklarında ise en fazla 19-29 yaşa aralığı daha sonra ise 30-40 yaş aralığında olduğu gözlemlenmiştir. Araştırmaya katılan katılımcıların yüksek oranda üniversite eğitimi aldığı gözlemlenmiştir. Demografik özelliklerde eğitim oranı incelendiğinde katılımcıların çoğunun eğitim seviyesinin yüksek olduğunu da söylemek mümkündür. Katılımcıların gelir seviyeleri incelendiğinde çoğunun $2500 \mathrm{TL}$ ve altında olduğu görülmektedir.

Bulgular incelendiğinde ise Bursa destinasyonunu genel olarak orta gelir seviyesine sahip turistlerin tercih ettiğini söylemek mümkündür. Bursa destinasyonu hakkında edilen bilgilerin genellikle akraba ve arkadaşlar aracılığıyla ya da sosyal medya aracılığıyla edinildiği gözlemlenmiştir. Bu sonuçtan yola çıarak Bursa destinasyonunun tanıtımına yönelik yapılan faaliyetlerin en başında sosyal medyayı aktif kullanarak turistlerin zihninde bir imaj oluşturmak oldukça önemli bir unsurdur. Araştırmanın bir diğer bulgusu ise ili ziyaret eden turistlerin deneyimlerini, yörenin mutfağını daha önce hiç denememiş kişilere olumlu bir şekilde anlatmasıdır. Bu sayede sosyal medyanın yanı sıra gelen turistlerinde destinasyon hakkında yansıttıkları olumlu deneyimleri destinasyonun pazarlaması açısından oldukça önemlidir.

Gelen turistlerin gerçekleştirmiş olduğu ziyaretlerinde Bursa iline geldiklerinde yemek kültürüne dair beklentilerin çok yüksek oranda karşılandığını söylemek mümkündür. Turistlerin beklentilerini en güzel şekilde karşılamak turizm açısından oldukça önemli bir unsurdur. Turizm endüstrisinde somut bir ürün satılmadığı için turistlerin daha önce denemesi gibi bir olanak yoktur. Yapılan tanıtımlar daha önce bu deneyimi hiç yaşamamış turistler açısından bir beklenti oluşturmaktadır. Bu beklentilerin karşılanmaması turistlerin zihninde olumsuz bir imaj yaratacaktır.

Araştırmada yer alan bir diğer önemli bulgu ise katılımcıların Bursa mutfağı denildiğinde akıllarına gelen ilk üç yiyecektir. Elde edilen sonuçlara bakıldığında Bursa İskender, kestane şekeri, pideli köfte 'nin en bilinen üç yiyecek olduğu gözlemlenmiştir. Bu üç popüler yiyeceğin yanı sıra cantık, süt helvası, şeftali, tahinli pide, Kemalpaşa tatlısı, zeytin gibi yiyeceklerinde turistler tarafından bilindiğini söylemek mümkündür. Ancak genel olarak bakıldığında ise katılımcıların bu yiyeceklerin yanı sıra hala tadına bakmadığı, ismini bile duymadığı yöresel yemeklerin olduğu gözlemlenmiştir. Anketin bir diğer bölümünde katılımcıların Bursa yemekleri ve Bursa'nın gastronomik marka kimliği hakkında düşüncelerini ölçmek için 5'li Likert tipi ölçek kullanılmış ve kişilerin düşüncelerini 1 ve 5 puan arasında değerlendirilmeleri istenmiştir. Bu puanlamalar değerlendirildiğinde katılımcıların çoğu Bursa yemeklerinin lezzetli olduğunu fakat yemeklerin yeterince çeşitli olmadığını düşünmektedir. Ancak araştırmada lezzet ve sunum faktörü yemeğin içeriğine nazaran daha fazla önemsenmekte olduğu gözlemlenmiştir. Ayrıca herhangi bir yaş grubuna ait katılımcıların yaşları ile yöresel yemeklere ait düşünceler arasında bir farklılık görülmediği tespit edilmiştir. Katılımcıların Bursa ilindeki yöresel yemeklerin tekrar denenmeye ve ziyaret etmeye değer olduğunu düşünmektedir. Yapılan araştırma katılımcıların düşüncelerinin olumlu olması Bursa şehrinin gastronomik açıdan bir imaj sahibi olduğunu ve destinasyonun pazarlanması açısından oldukça önemli bir pazarlama aracı olduğu söylenebilir.

Bursa ilinin gastronomik marka kimliği hakkındaki ifadeler bakıldığında katılımcıların çoğunun Bursa mutfağının şehir turizmi için önemli bir unsur olduğunu düşündüğünü görmek mümkündür. Ayrıca yöre mutfağının şehrin marka algısını arttırdı̆̆ı ve gelen ziyaretçilerin artmasında da önemli bir rol oynadığı düşünmektedir. Katılımcılar yöredeki yemeklerin ve yöresel ürünlerin satın almaya değer olduğunu ve yörenin ülke çapında bilinen lezzetlere sahip olduğunu düşünmektedir. Ancak yöre mutfağının yapılan tanıtımlar ile tanınmaya başladığı 
Türk Turizm Araştırmaları Dergisi, 4(4): 3226-3248.

konusunda katılımcıların çoğunun kararsız olduğu gözlemlenmiştir. Ayrıca Bursa mutfağının bir marka değerine sahip olduğunu düşünen fakat tanıtım konusunda kararsız kalan ve olumsuz düşünen katılımcı sayısı oldukça fazladır.

Elde edilen bu sonuçlar doğrultusunda katılımcıları Bursa mutfağı hakkında düşüncelerinin çoğunun olumlu olduğu gözlemlenmiş ancak pazarlama faaliyetlerinin yetersiz kaldığ görülmüştür. Ayrıca katılımcıların Bursa ili hakkında bilgiye sahip olduğunu fakat yöre mutfağı hakkında az bilgiye sahip olduğu gözlemlenmiştir. Ancak katılımcıların bu lezzetleri deneyimlediklerin de beğendikleri hatta yörenin kültürünü yansitmakta olduğunu düşündüğünü söylemek mümkündür.

Araştırmanın sonuçlarına bakıldığında Bursa ilini gastronomisinin destinasyon pazarlaması açısından önemini arttırmak için yapılabilecek öneriler şu şekildedir:

- Araştırma sadece Bursa ilinde bulunan turistler açısından popüler olan birkaç turistik alanda ve gerçekleştirilmiştir. Bursa'nın tamamını kapsayan bir araştırma yapılması önerilir.

- Araştırmaya sadece ili ziyaret eden yerli turistler dâhil edilmiştir. Daha sonra yapılacak olan araştırmalara yabancı turistlerin araştırmaya dâhil edilmesi ve düşüncelerinin alınması ve yöre halkının da yapılan tanıtımlara katkıları, turistleri karşı tutumlarının öğrenilmesi de destinasyonun pazarlanması açısından yol gösterici olabilecektir.

- Bursa'nın yemek kültürüne has yiyeceklerinin geçmişten günümüze geçirdiği değişim ve gelişimlerde göz önünde bulundurularak sahip çıkılmalı ve gelecek nesillere aktarılmalıdır.

- Bursa İl Kültür ve Turizm Müdürlügü ile beraber sosyal medya, televizyon, dergi gibi tanıtım yerlerinde yöresel gastronomi ile detaylı bilgiler görseller ile desteklenmeli ve akılda kalıcı bir etki oluşturmalıdır.

- Bursa yöresine ait yöresel yemekleri tanıtan herhangi bir kitap bulunmamakta, olanlarda oldukça eski basım oldukları için ulaşılması neredeyse imkânsızdır. Bu açıdan bakıldığında yöreyi ve yöresel yemekleri tanıtan kitaplar, dergiler basılabilir. Ayrıca farklı dillerde de yayımlanarak daha geniş bir kitleye ulaşılabilir.

- Bursa yöresel yemeklerinin yanı sıra hem tarihi güzellikleri hem de kış turizmi ile oldukça dikkat çeken bir destinasyondur. Bu yüzden turistlerin yoğun olduğu dönemlerin tespit edilerek yapılacak olan tanıtım çalışmaları turistler için olumlu bir imaj yaratmaya katkı sağlayabilir.

- Bursa destinasyonu İskender, Kestane şekeri gibi bilinen lezzetlerinin yanı sıra unutulmaya yüz tutmuş pek çok lezzete sahiptir. Bu yemekleri araştıran birimler kurularak gelecek nesillere eğitim verilebilir.

- Tur acenteleri Bursa mutfağının Osmanlı Devlet'inden bu yana değişimini anlatan tur programları düzenleyebilir.

- Yöresel yemekleri sunan işletmelere yemeklerin hazırlanması, sunulması hakkında turistlerin dikkatini çekebilecek bilgiler verilerek, eğitilebilir.

- Yöreye ait yemek pişirme teknikleri, kullanılan malzemeler, yöreye özgü yiyeceklerin çeşitleri, bu yörede yetişen ürünlerin içeriği hakkında bilgiler bir araya getirilerek kent arşivine eklenebilir. Böylece gelecek nesillere ve gelecek araştırmalara 1şık tutması sağlanabilir.

- Cumalıkızık köyünde kahvaltı yapılan mekânlara hiç dokunmadan günümüze kadar korunması sağlanmıştır. Bu şekilde şehir içine de benzer buna benzer bir yer oluşturularak Bursa yöresini tanıtan faaliyetler düzenlemek şehir merkezindeki turist hareketliliğin daha çok arttırabilir. 
- Yerel yönetimler ve SKT tarafından kültürel miras olarak yemek kültürünün korumak ve tanıtmak adına çalışmalar yapılmalıdır.

- Bursa mutfağı hakkında yapılacak olan çalışmalar için öğrenciler teşvik edilmeli ve bu konuda yardımcı olacak faaliyetler düzenlenmelidir.

\section{KAYNAKÇA}

Akkoyunlu, G. Ş. ve Kalyoncuoğlu, S. (2014). İşletmelerin Kurumsal Sosyal Sorumluluk Çalışmalarının Marka Algısı Üzerine Etkisinin Değerlendirilmesi, Niğde Üniversitesi İktisadi ve İdari Bilimler Fakültesi Dergisi, 7(3): 125-144.

Akyurt, H. ve Atay, L. (2009). Destinasyonda Marka Oluşturma Süreci, Aksaray Üniversitesi İ̈BF Dergisi, 1(1): 1-14

Atılgan, S. S. ve Karapınar, M. (2015). Turizm Pazarlama ve Tanıtımında Web Siteleri Portalı İncelemesi, Atatürk Illetişim Dergisi, (9): 113-124.

Avcılar, M. Y. ve Varinli, İ. (2013). Perakende Marka Değerinin Ölçümü ve Yapısal Eşitlilik Modeli Uygulaması, Ankara: Detay Yayıncilık.

Aydın, E. (2015). Gastronomi Turizminin Şehir Markalaşmasına Etkisi: Afyonkarahisar İli Örneği. Yüksek Lisans Tezi, Afyonkarahisar.

Bahar, O. ve Kozak, M. (2005). Türkiye Turizminin Akdeniz Ülkeleri İle Rekabet Gücü Açısından Karşılaştırılması, Anatolia: Turizm Araştırmaları Dergisi, 16(2): 139-152.

Bişkin, F. (2014). Markanın Pazarlama Açısından Önemi ve Tüketici Açısından TercihleriMemnuniyet Çerçevesinde Otomobil Sahipleri Üzerine Bir Araştırma, SÜ İ̈BF Sosyal ve Ekonomik Araştırmalar Dergisi, (2): 411-433.

Bucak, T. ve Aracı, Ü. E. (2013). Türkiye'de Gastronomi Turizmi Üzerine Genel Bir Değerlendirme, Balıkesir Üniversitesi Sosyal Bilimler Üniversitesi, 16(30): 203-216.

Choe, J.Y. and Kim, S. (2018). Effects of tourists' local food consumption value on attitude, food destination image, and behavioral intention, International Journal of Hospitality Management, 71, 110. https://doi.org/10.1016/j.ijhm.Erişim Tarihi: 2017.11.07.

Çağlıyan, V. Şahin, E. ve Selek, N. (2018). Öğrencilerin Marka Farkındalığının, Marka İmajı ve Marka Güvenine Etkisi: Selçuk Üniversitesi, İiBF Örneği, Selçuk Ün. Sos. Bil. Ens. Dergisi, 40, 186198.

Çalışkan, O. (2013). Destinasyon Rekabetçiliği ve Seyahat Motivasyonu Bakımından Gastronomik Kimlik, Journal of Tourism and Gastronomy Studies, 1(2): 39-51.

Döner, Ş. M. (2019). Marka Kişiliği ile Marka Kimliği İlişkisi, Marka Kimliğinin Marka Sadakati ve Satın Alma Niyeti Üzerindeki Etkisi: Bir Vakıf Üniversitesi Öğrencileri Üzerine Bir Araştırma. İstanbul: Beykent Üniversitesi Sosyal Bilimler Enstitüsü.

Durmaz, Y. , ve Ertürk, S. (2016). Marka Uygulamaları ve Önemi, Internatonal Journal of Academic Value Studies. 2(2), 82-93.

Eren, R. ve Çelik, M. (2017). Çevrimiçi Gastronomi İmajı: Türkiye Restoranlarının Tripadvisor Yorumlarının İçerik Analizi, Turizm Akademik Dergisi, 4 (2): 121-138.

Ersoy, M. (2019). Destinasyon Pazarlaması Çerçevesinde Akşehir'in Turizm Potansiyelinin Değerlendirilmesi, Yüksek Lisans Tezi, KTO Karatay Üniversitesi Sosyal Bilimler Enstitüsü, Konya. 
Türk Turizm Araştırmaları Dergisi, 4(4): 3226-3248.

Gökdeniz, A. Erdem, B. Dinç, Y. ve Uğuz, Ç. S. (2015). Gastronomi Turizmi: Ayvalık'ta Yerli Turistler Üzerinde Görgül Bir Araştırma. Journal of Tourism and Gastronomy Studies, 3(1): 14-29.

İlban, M. O. Köroğlu, A. Bozok, D. (2008). Termal Turizm Amaçlı Seyahat Eden Turistlerde Destinasyon İmajı: Gönen Örneği, İstanbul Ticaret Üniversitesi Sosyal Bilimler Dergisi, 10(1): 105129.

İnaç, H. ve Yacan, İ. (2018). Ülkelerin Markalaşma Süreci ve Marka Kavramı, Uluslararası Yönetim Akdemisi Dergisi, 1(3): 317-331.

Kahraman, M. (2017). Yerli Turistlerin Gaziantep Mutfă̆ına Bakış Açılarının Tespit Edilmesine Yönelik Bir Araştırma, Yüksek lisans Tezi, Gaziantep Üniversitesi Sosyal Bilimler Enstitüsü, Gaziantep.

Kargiglioğlu, Ş. (2015). Gaziantep'te Gastronomi Turizmi: Gaziantep'i Gastronomi Turizmi Kapsaminda Ziyaret Eden Yerli Turistlerin Görüşleri Üzerine Bir Araştırma, İzmir Kâtip Çelebi Üniversitesi Sosyal Bilimler Enstitüsü Turizm İşletmeciliği Anabilim Dalı. İzmir.

Kerimoğlu, E. and Çıracı, H. (2007). The Evaluation of Istanbul as a Major Urban Destination with Respect to International Visitor's Expectations, International Conference on Advances in Tourism Economics, Vila Nova de Santo Andre, Portugal, April 13-17.

Köroğlu, A. ve Güzel, Ö. (2007). Türkiye İmajının Geliştirilmesinde Profesyonel Turist Rehberinin Rolünü Belirlemeye Yönelik Alman Turistler Üzerine Bir Araştırma, I. Ulusal Türkiye Turizm Kongresi, Sakarya.

Kurtbaş, İ. (2016). Marka Yönetimi ve Başarılı Markanın Yarar ve Etkileri. Karadeniz Uluslararası Bilimsel Dergi, 32(32): 75-98.

Lopes, S. F. (2011). Destination Image: Origins, Developments and Implications, Revista de Tourismo Patrimonio Cultural, 9(2): 305-315.

Özdemir, G. (2007). Destinasyon Yönetimi ve Pazarlama Temelleri İzmir İçin Bir Destinasyon Model Önerisi, Yayınlanmış Doktora Tezi, Dokuz Eylül Üniversitesi Sosyal Bilimler Enstitüsü, İzmir.

Özer, Ö. (2012). Destinasyon Tercihinde Pazarlama Karması Bileşenlerinin Rolü: Dalyan Örneği, İsletme Araştırmaları Dergisi, 4(1): 163-182

Özüpek, N. ve Diker, E. (2013, Ocak). İletişim Fakültesi Öğrencilerinin Cep Telefonu Markalarına Yönelik İmaj Algısı: Nokıa ve Samsung Örneği. e-Journal of New Sciences Academy, 8(1): 100-120.

Serçeoğlu, N. Boztoprak, F. ve Tirak, L. (2016). Gastronomi Turizmi İle Şehir Markalaşması İlişkisi: Atatürk Üniversitesi Öğrencileri Üzerine Bir Araştırma, Journal of Tourism and Gastronomy Studies, 4(2): 94-114.

Sever, P. ve Girgin, K. G. (2019). Turistlerin Restoran Deneyimle ile Destinasyonu Tekrar Ziyaret Etme Niyeti Arasındaki İlişkinin Belirlenmesi: İstanbul Örneği. Gastroia: Journal of Gastronomy and Travel Research, 3(2): 241-263.

Tosun, C. and Jenkins, C. L. (1996). Regional planning approaches to tourism development: The case of Turkey. Tourism Management, 17(7): 519-531

Tunç, A. (2003). Dünyada'ki Türkiye İmajının Turizm Sektörüne Etkisi ve Bir Uygulama, Gazi Üniversitesi Ticaret ve Turizm Eğitim Fakültesi Dergisi, 1, 38-54.

Turan, H. (2017). Pazarlama Yönetiminde Marka İmajı Algısı ile Müşteri Sadakat Düzeyleri Arasındaki İlişkisinin İncelenmesi, Uluslararası Sosyal Araştırmalar Dergisi, 10(48): 653-658.

Türk Dil Kurumu, (2019). Erişim adresi: https: //sözlük. gov. tr/?kelime=Erişim tarihi: 05 Eylül 2020. 
Aydın YILMAZER, Ebru Ö. GÜVEN ve Kezban GÜLŞEN

Uztuğ, F. (2002). Markan Kadar Konuş: Marka İletişim Strajileri, İstanbul: Mediacat Kitapları.

Yaraşlı, G. Y. (2007). Destinasyon İmajı ve Trabzon Yöresine Dönük Bir Çalışma, Yüksek Lisans Tezi, Başkent Üniversitesi Sosyal Bilimler Enstitüsü, Ankara.

Yarış, A. (2014). Mardin'de Gastronomi Turizmi: Turist Görüşlerine İlişkin Bir Uygulama. Yüksek Lisans Tezi, Mardin.

Zengin, B. ve Vatan, A. (2019). Destinasyon Pazarlaması Kapsamında Bilecik İli Turizminin Değerlendirilmesine Yönelik Paydaş Analizi, Selçuk Üniversitesi, Sosyal Bilimler Meslek Yüksekokulu Dergisi, 22(1): 272-288. 